The following locality record extends the range to another country: one female, Vipya Plateau, 12 miles northeast of Mzimba, Malawi, 5200 feet altitude, 15 April 1967 (C. D. Michener).

\section{Thrinchostoma (Thrinchostoma) afasciatum new species \\ Figures 84,86}

This species is described here because it has certain characters not otherwise found in the genus which must therefore be accounted for in the generic description. The short malar space, only one third as long as broad or perhaps less, distinguishes this species from all others except $T$. sladeni Cockerell (see Blüthgen, 1926) from Assam. The most remarkable feature, however, is the lack of the bands of pale (usually silvery), laterally directed hairs on the posterior marginal areas of the metasomal terga. Such bands characterize all other species of the genus. The incompletely described T. bryanti Meade-Waldo, 1914, also from Borneo, could be the male of T. afasciatum. It has black head and thorax, probably lacks radiating striae in the propodeal triangle, and thus seems likely to be different although the description says nothing of the apical tergal bands.

Female: Length $9.5 \mathrm{~mm}$. Head brownish black; labrum, malar area, clypeus, and lower part of paraocular area testaceous, this color grading into the dark color of rest of head, supraclypeal area and hypostomal area being largely reddish brown. Mandible testaceous except for dark brown apex. Antenna brownish black except base of scape and under sides of segments 7-12 testaceous. Thorax and legs testaceous except for mesoscutum which is dusky brownish, grading to testaceous posteriorly. Wings yellowish, veins and stigma dusky brown, at extreme wing bases testaceous, also veins forming marginal cell beyond stigma and beyond third transverse cubital vein testaceous. First metasomal tergum and narrow basal bands on terga 2-4 testaceous; broad apical bands on terga 1-4 transparent so that basal testaceous bands on terga 2-4 show through; rest of metasomal dorsum brownish black; metasomal venter brown, testaceous basally.

Hair of head dull yellowish white, some of long hairs dusky in certain lights; subappressed plumose hairs almost hiding surface of lower part of paraocular area laterally; short subappressed hairs also abundant, but not obscuring surface on rest of paraocular area, frons, vertex and genal areas; long, simple, mostly subserect hairs present on most of head, unusually long, yellowish, and strongly directed forward on supraclypeal area, clypeus, mandible, hypostomal area, and lower genal area. Thoracic hair colored like that of head, short whitish hairs abundant on pleura, sides and posterior face of propodeum, and on metanotum; longer erect hairs mostly simple and dusky in certain lights dorsally, paler and often coarsely plumose laterally. Hairs of legs pale testaceous, golden on under sides of tibiae and tarsi. Metasomal hair dull yellowish white, long erect dorsal hairs dusky in certain lights; transparent marginal bands of terga 1-4 with only scattered, short, laterally directed hairs.

Head broader than thorax, clypeus 2.5 times as broad as long, not much produced downward nor protuberant anteriorly; inner orbits not strongly converging below (Fig. 86); line tangent to lower ends of eyes only a little above middle of clypeus; antennal sockets separated by more than diameter of a socket; antennocular distance about twice diameter of antennal socket; malar area about three times as wide as shortest length; mandible long, less strongly curved than in the forms with a more produced clypeus; first flagellar segment slightly longer than broad, middle segments markedly so. Interocellar distance much less than ocellocular distance. Genal area about as broad as eye seen from side. Glossa distinctly longer than length of head, apical fourth without long hairs. Inner hind tibial spur as in Figure 84. Scutellum bigibbous; dorsum of propodeum longer than scutellum. Forewing with basal vein and $\mathrm{m}$-cu interstitial; submarginal cells as in Figure 81; hairs denser around the medially thickened second transverse cubital vein than elsewhere.

Clypeus and supraclypeal area shining, with coarse punctures, some of them longitudinally elongate, irregularly placed, but mostly about a puncture width apart; rest of head and thorax with minute punctures, widely separated on scutum, the center of which is shining and impunctate, scutellar gibbosities also shining and impunctate; sides of thorax mostly minutely roughened and dull; propodeal triangle large, nearly reaching declivity, with strong, regular, radiating ridges. Metasomal terga grading from the first which is shining with only scattered minute punctures to the fifth which has a dull surface and scattered small punctures; posterior transparent margins of terga IIV impunctate, shining on tergum I, progressively duller on succeeding terga.

Holotype female: Pontianak, Borneo (Kalimantan, Indonesia) (F. Muir) in the collection of the Bishop Museum, Honolulu.

The specific name is based on $a$, without, plus fasciatus, banded, with reference to the lack of apical tergal bands of later- 
ally directed silvery or golden hairs, characteristic of other species of the genus.

\section{Halictus (Seladonia) lutescens Friese, 1921}

Halictus ruae Cockerell, 1949, Proc. U. S. Nat. Mus., 98:446 (new synonym).

Type of ruae in National Museum of Natural History, Washington, D.C.

\section{Literature Cited}

Blüthgen, P. 1920, 1921. Die deutschen Arten der Bienengattung Halictus Latr. Deutsche Ent. Zeitschr., 1920:81-132, 1921:267-302.

1923a. Beiträge zur Kenntnis der Bienengattung Halictus Latr. Arch. Naturg., 89(2):232-332.

. 1923b. Beiträge zur Systematik der Bienengattung Halictus Latr. Konowia, 2:65-142.

- 1924. Contribución al conocimiento de las especies españolas de "Halictus." Mem. Real Soc. Española Hist. Nat., $11: 331-544$.

. 1925. Die Bienengattung Nomioides Schenck. Stettiner Ent. Zeitung, 86: 1-100.

. 1926. Beiträge zur Kenntnis der indo-malayischen Halictus- und Thrincostoma-Arten. Zool. Jahrb. (Syst., Geogr. Biol. Tiere), 51:375-698, pls. 4-5.

1928. Beiträge zur Kenntnis der indo-malayischen Halictus- und Thrincostoma-Arten, 1. Nachtrag. Zool. Jahrb. (Syst., Geogr. Biol. Tiere), 54: 343-406.

. 1931. Beiträge zur Kenntnis der indo-malayischen Halictus- und Thrincostoma-Arten. Zool. Jahrb. (Syst., Geogr. Biol. Tiere), 61:285-346.

- 1934. 1. Nachtrag zur Monographie der Bienengattung Nomioides Schenck. Stettiner Ent. Zeitung, 95:238-283.

Ebmer, A. W. 1969. Die Bienen des Genus Halictus Latr. s.l. im Grossraum von Linz. Naturkundliches Jahrbuch der Stadt Linz, 133-183.

- 1974. Von Linné bis Fabricius beschriebene westpaläarktische Arten der Genera Halictus und Lasioglossum. Nachrichtenbl. Bayerischen Ent., 23: 111-127.

1976a. Halictus und Lasioglossum aus Marokko. Linzer Biol. Beitr., 8: 205-266.

1976b. Liste der mitteleuropäischen Halictus- und Lasioglossum-Arten. Linzer Biol. Beitr., 8:393-405.

Eickwort, G. C. 1969. A comparative morphological study and generic revision of the augochlorine bees. Univ. Kansas Sci. Bull., 48:325-524.

Latreille, P. A. 1810. Considerations générales sur l'ordre natural des animaux composant les classes des crustaces, des arachnides, et des insectes. Schoell, Paris.

Michener, C. D. 1951. Halictidae in C. F. W. Muesebeck, K. V. Krombein and H. K. Townes, Hymenoptera of America North of Mexico-Synoptic Catalog, U. S. Dept. Agric. Monogr. no. 2.

1978. The parasitic groups of Halictidae (Hymenoptera, Apoidea). Univ. Kansas Sci. Bull., 51:291-339.

Sakagami, S. F. and F. L. Wain. 1966. Halictus latisignatus Cameron: a polymorphic Indian halictine bee with caste differentiation. Jour. Bombay Nat. Hist. Soc., 63:57-73.

Sandhouse, G. A. 1941. The American bees of the subgenus Halictus. Ent., Americana, (ns) 21:23-39.

Warncke, K. 1970. Beitrag zur Systematik und Verbreitung der Bienengattung Prosopis F. in der Westpaläarktis. Bull. Recherches Agronom. Gembloux, (NS) 5:754-768.

—. 1975. Beitrag zur Systematik und Verbreitung der Furchenbienen in der Türkei. Polskie Pismo Ent., 45:81-128.

Wille, A. and C. D. Michener. 1971. Observations on the nests of Costa Rican Halictus with taxonomic notes on Neotropical species. Rev. Biol. Tropical, 18:17-31. 


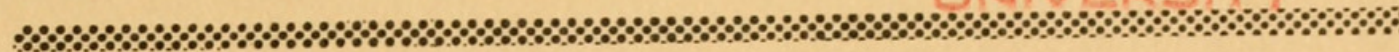

\title{
THE UNIVERSITY OF KANSAS
} SCIENCE BULLETIN

\author{
A NEW GENUS OF CRYPTODIRAN \\ TURTLES (TESTUDINOIDEA, \\ CHELYDRIDAE) \\ FROM THE UPPER CRETACEOUS HELL \\ CREEK FORMATION OF MONTANA
}

By

KENNETH N. WHETSTONE 


\section{ANNOUNCEMENT}

The University of Kansas Science Bulletin (continuation of the Kansas University Quarterly) is an outlet for scholarly scientific investigations carried out at the University of Kansas or by University faculty and students. Since its inception, volumes of the Bulletin have been variously issued as single bound volumes, as two or three multi-paper parts or as series of individual papers. Issuance is at irregular intervals, with each volume prior to volume 50 approximately 1000 pages in length. Effective with volume 50 , page size has been enlarged, reducing the length of each volume to about 750 pages.

The supply of all volumes of the Kansas University Quarterly is now exhausted. However, most volumes of the University of Kansas Science Bulletin are still available and are offered, in exchange for similar publications, to learned societies, colleges and universities and other institutions, or may be purchased at $\$ 20.00$ per volume. Where some of these volumes were issued in parts, individual parts are priced at the rate of 2 cents per page. Current policy, initiated with volume 46, is to issue individual papers as published. Such separata may be purchased individually at the rate of 3 cents per page, with a minimum charge of $\$ 1.00$ per separate. Subscriptions for forthcoming volumes may be entered at the rate of $\$ 20.00$ per volume. All communications regarding exchanges, sales and subscriptions should be addressed to the Exchange Librarian, University of Kansas Libraries, Lawrence, Kansas 66045.

Reprints of individual papers for personal use by investigators are available gratis for most recent and many older issues of the Bulletin. Such requests should be directed to the author.

The International Standard Serial Number of this publication is US ISSN 0022-8850.

\section{Editor}

Eugene C. Bovee

\section{Editorial Board}

William L. Bloom

Philip W. Hedrick

Rudolf Jander

Harvey Lillywhite

Charles D. Michener

Norman A. Slade

Henry D. Stone

George W. Byers, Chairman 


\section{THE UNIVERSITY OF KANSAS SCIENCE BULLETIN}

Vol. 51, No. 17, pp. 539-563

November 16, 1978

A New Genus of Cryptodiran Turtles (Testudinoidea, Chelydridae) From the Upper Cretaceous Hell Creek Formation of Montana

Kenneth N. Whetstone

\section{TABLE OF CONTENTS}

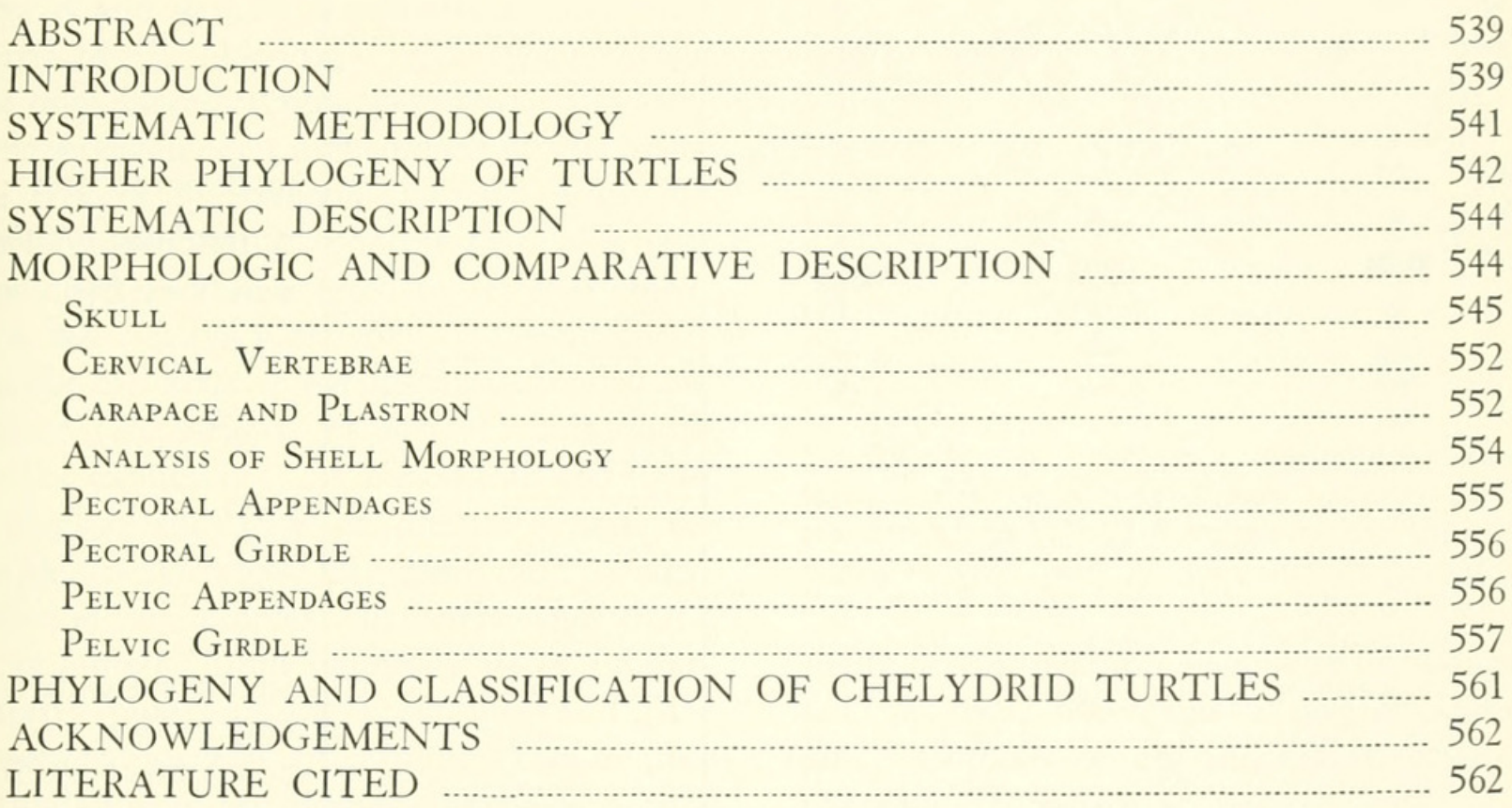

\section{ABSTRACT}

Emarginachelys cretacea is described as a new genus and species of cryptodiran turtle and is placed in the Chelydridae on the basis of shared derived characters. The holotype is a nearly complete skeleton from the Hell Creek Formation (Maestrichtian) of Montana. Emarginachelys is the oldest known member of the superfamily Testudinoidea as defined by Gaffney (1975a). The Chelydridae are hypothesized to be a monophyletic group, sharing a cruciform plastron ligamentously attached to the carapace, a reduced entoplastron, long costiform processes on the nuchal bone, an elongate jugal, and the pectineal processes of the pubis not strongly divergent. Emarginachelys is hypothesized to be the most primitive genus of the Chelydridae since it does not have the derived characters shared by advanced chelydrids. Advanced chelydrids have the frontal bones separated from the orbital rim, a premaxillary "hook," constriction of the otic bridge, a closed incisura columella auris, a serrated carapacial margin, and peripheral fontanelles.

\section{INTRODUCTION}

The turtle superfamily Testudinoidea includes the majority of living turtles, both in numbers and diversity. As defined by Gaffney (1975a), the testudinoids include the pond turtles (Emydinae and Batagurinae), the tortoises (Testudininae), and the snapping turtles (Chelydridae). Previously, the oldest known definitive testudinoids were a 
chelydrid, Protochelydra zangerli, from the Paleocene of North Dakota (Erickson, 1973), and a pond turtle, Ptychogaster sp., from the Paleocene of the Big Horn Basin in Wyoming (Estes, 1975). The family Chelydridae has a sparse fossil record in Tertiary deposits of North America and Europe, and only two species are extant, both restricted to the New World (Fig. 1). Gaffney (1975b) includes the Recent Asiatic genus Platysternon in the Chelydridae, but I do not consider this to be a parsimonious interpretation of the affinities of this genus (see discussion below).

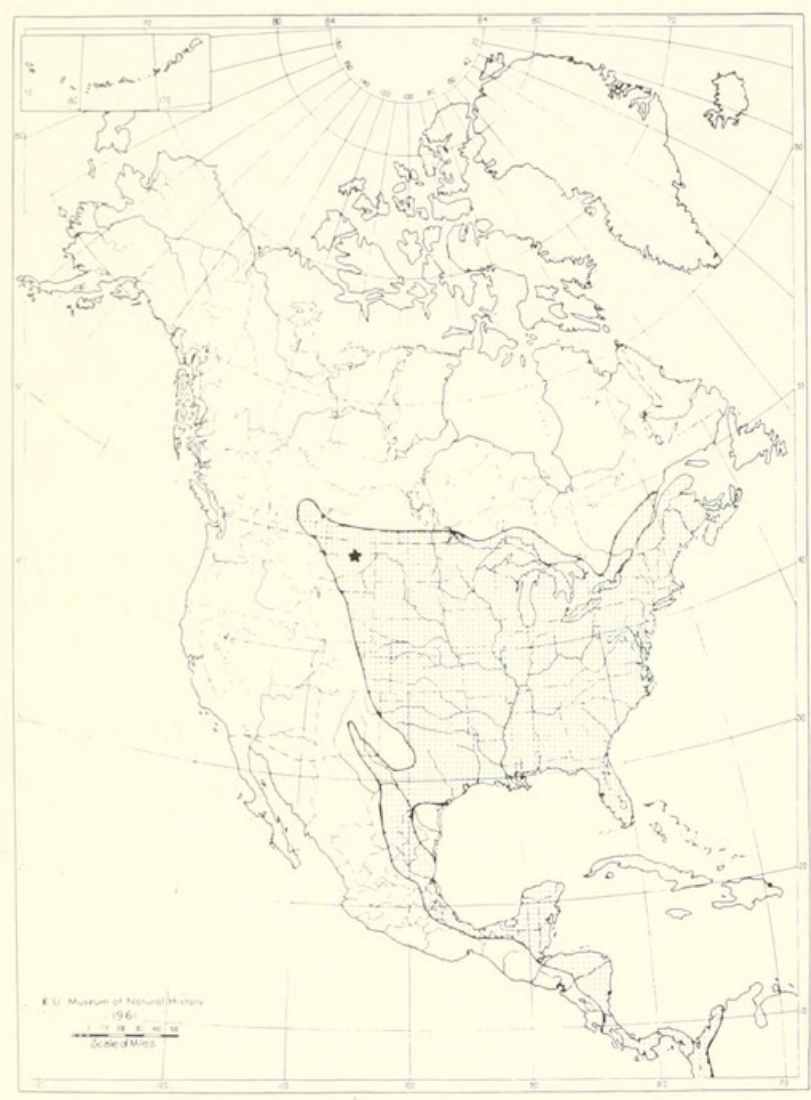

FIG. 1. Generalized distribution of recent chelydrid turtles. Star shows location from which the holotype of Emarginachelys was recovered.

The species described herein as Emarginachelys cretacea $\mathrm{n}$. gen. et sp. is the oldest and most primitive species placed in the Chelydridae. A University of Kansas field party (Don and Stan Rasmussen and John Chorn) collected the holotype in 1971 from the Upper Cretaceous Hell Creek Formation in Montana. The type specimen is a nearly complete skeleton, still mainly articulated when found. Fossil turtles of this quality are extremely rare, especially in Mesozoic strata.
The turtle was preserved as a large "clast" in a medium grained sandstone which lies $5.2 \mathrm{~m}$. (27 feet) below the " $Z$ " coal of the Paleocene Ft. Union Formation (Fig. 2).

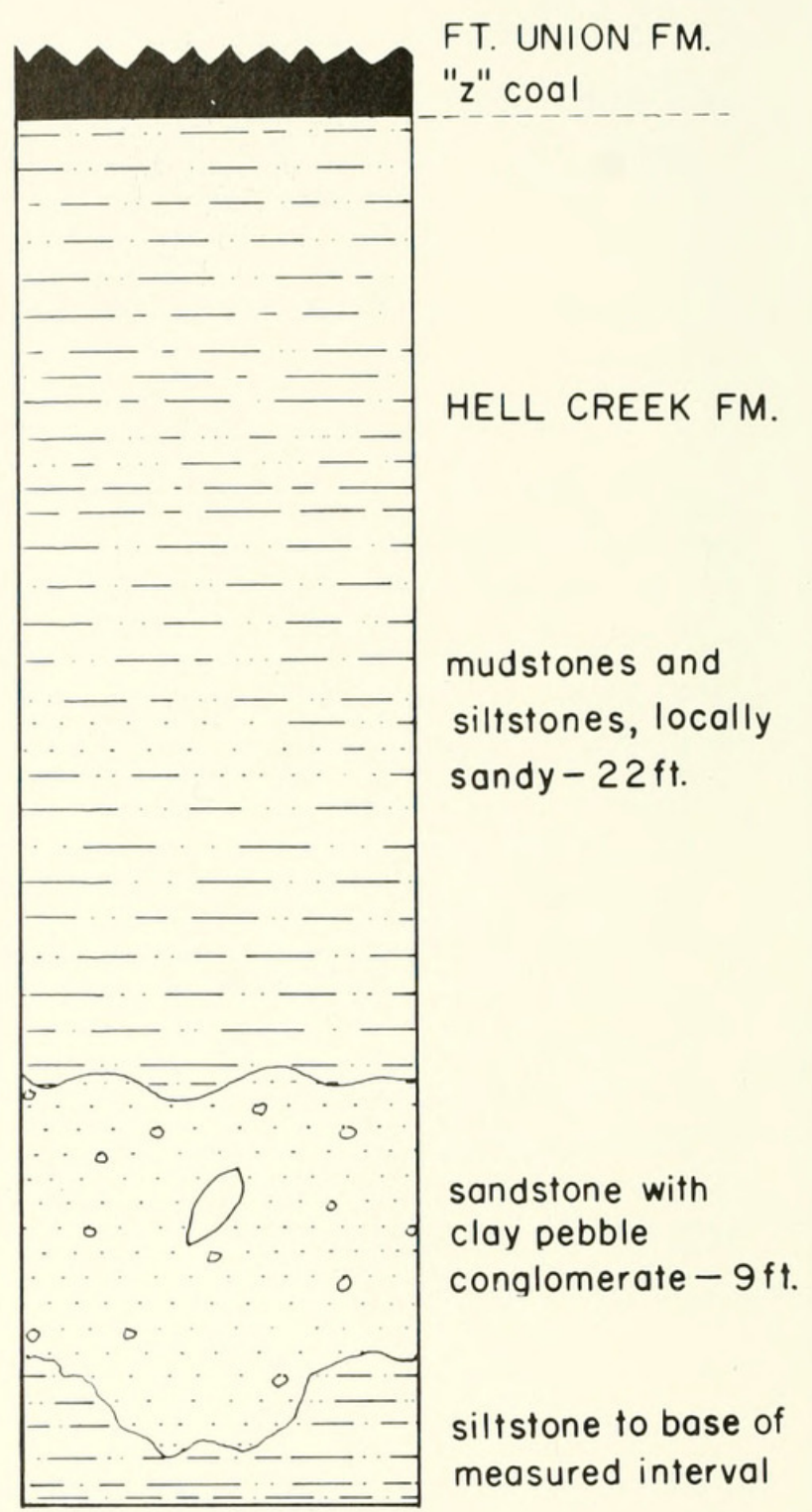

FIG. 2. Geologic section at type locality.

The Hell Creek Formation is Upper Cretaceous (Maestrichtian) in age, its uppermost strata Potassium-Argon dated at roughly 63 million years old (Gill and Cobban, 1973). The vertebrate fossils found with the specimen included scales of ganoid fishes, crocodile teeth and bones, and indeterminate dinosaur fragments. In the older literature, the Hell Creek beds were considered part of the Lance Formation, and Hell Creek specimens were often described as "from the Lance," or "from the Laramie Cretaceous" (e.g., Hay, 1908). Turtles previously known from the 
Hell Creek Formation include the following baenid genera (Gaffney, 1972a): Hayemys, Plesiobaena, Eubaena, Stygiochelys, Palatobaena, and Neurankylus. Trionychids (soft shelled turtles) have been found in the Hell Creek, Lance, and Judith River Formations.

\section{SYSTEMATIC METHODOLOGY}

In this study, I name, diagnose, and describe a new taxon and formulate a hypothesis of its phylogenetic relationships.

A phylogenetic hypothesis must take the form of a three-taxon statement of the sort, "taxa A and B share a common ancestor not shared by C." Hennig $(1950,1966)$ shows that only shared, uniquely-derived characters (synapomorphies) can demonstrate the relative recency of common descent. A phylogenetic hypothesis is tested against alternate hypotheses and is accepted or rejected based upon the relative parsimony of the alternate hypotheses. Relative parsimony is decided by way of (cf. Nelson, 1970): (1) minimum parallel evolution, (2) anatomical and embryological similarity of presumed synapomorphous characters, (3) minimum parallel evolution of complex characters and characters buffered from requirements of similar adaptive modes of the organisms, and (4) minimum reversal of evolutionary trends. Formulation of phylogenetic hypotheses, and testing them using synapomorphous char-" acters, are herein called "Hennigian analysis," instead of "cladistic analysis." Hennigian analysis provides a corroborated hypothesis of the relative recency of common ancestry, which is then used to nest monophyletic taxa into more inclusive monophyletic groups. Hennigian analysis cannot selectively test the several, alternate, geometric arrangements for only two populations (Fig. 3).

Gaffney (1972a) and Tattersall and Eldredge (1977) contend that the geometry of evolution cannot be tested beyond conventional Hennigian analysis, such hypotheses as are presented in Figure 3 being untestable conjectures. Martin and Whetstone (Ms.) argue that the following criteria will objectively test the various geometrical combinations of evolution: 1) except for evolutionary reversals, which must be assumed to be rare, a direct ancestor must be primitive (plesiomorphic) for every character whereby it differs from daughter populations, 2) a proposed daughter population cannot predate a hypothesized ancestor, 3) a proposed ancestor which postdates or is contemporaneous with a hypothesized daughter population refutes a hypothesis of a single evolutionary lineage without a cladistic event (Fig. 3-1). Despite its geological age, Emarginachelys possesses

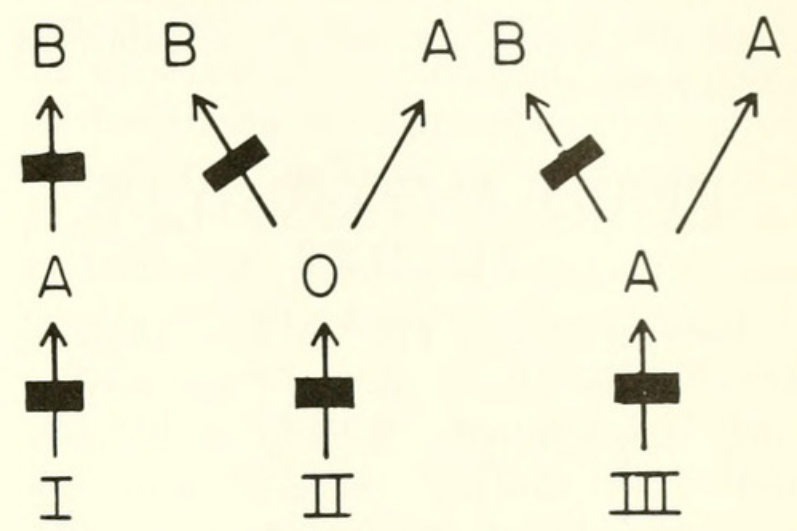

FIG. 3. Alternate hypotheses of phylogenetic linkage between two "taxa." Solid bars represent derived character states. Model II represents the hypothesis that neither " $\mathrm{A}$ " nor " $\mathrm{B}$ " is ancestral to the other.

many derived features, especially of braincase and plastron, which make unparsimonious any hypothesis of an ancestral position to other known chelydrids.

A thoroughly nested classification presumes coordinate rank of sister taxa. If this concept is used to name each coordinate sister group pair, classifications rapidly become unwieldy and unstable. New names, names of new rank, and a superfluous number of monotypic higher taxa often result (e.g., McKenna, 1975, and Gaffney, 1977). Gaffney (1977), however, argues that "although stability is often considered an important quality of classifications, . . . it is often a spurious and misleading indication of phylogenetic 'truth'." These problems increase markedly with the incorporation of fossil taxa, not because fossil taxa are inherently different, but because many higher taxa must be employed to deal with them.

Patterson and Rosen (1977) suggest a different approach to the classification of 
fossils, namely, that "fossil groups or species, sequenced in a classification according to the convention that each group is the (plesiomorph) sister group of all those living and fossil that succeed it, should be called 'plesions.' Plesions may be inserted anywhere (at any level) in a classification without altering the rank or name of any other group. They may bear a categorical name representing any conventional rank, from genus and species upward ...., these ranks being those already existing in the literature, used only for reference and to avoid ambiguity." I adopt this convention in the classification which follows.

\section{HIGHER PHYLOGENY OF TURTLES}

Prior to Gaffney (1975a) most Mesozoic turtles were placed in the "wastebasket" taxon Amphichelydia, thought to be intermediate in structure between living crypotodires and pleurodires. Gaffney presents a convincing shared derived character analysis for a basic crypotodire-pleurodire dichotomy and redistributes most of the taxa previously assigned to the Amphichelydia. The more basic differences between crypotodires and pleurodires are in the trochlear system of the skull for the adductor jaw muscu'ature and the akinetic modifications of the braincase and "palatoquadrate." Cryptodires have a processus trochlearis oticum and a pterygoid brace to the braincase, while pleurodires have a processus trochlearis pterygoidei and a quadrate brace.

Within the Cryptodira, Gaffney recognizes four superfamilies, the Baenoidea, Chelonioidea, Trionychoidea, and the Testudinoidea. In the Trionychoidea he places the kinosternids, dermatemydids, trionychids, and Carretochelys, based on the reduction of the stapedial artery and the presence of the "caudifibularis" muscle (Zug, 1971), both assumed to be synapomorphous. Trionychoids also have the costal bones meeting behind the neurals, a reduced postorbital bone, and lack a biconvex 4th cervical vertebra,

If based solely upon the arterial condition and the musculature, a hypothesis of mono- phyly for these taxa would be questionable. The reduction of the stapedial artery in kinosternids and Dermatemys results from enlargement of the palatine artery, while in trionychids and Carretochelys it is the result of the enlargement of the pseudopalatine artery (McDowell, 1961; Albrecht, 1967). Neither arterial condition seems intermediate to the other and I suggest that they are nonhomologous. Walker (1973) has interpreted Zug's "caudifibularis" as the dorsal head of the M. flexor tibialis externus that has shifted its insertion from the tibia (the primitive insertion found in most turtles) to the fascia overlying the tibia. This muscle shift is found in all trionychoids, but it is not of such complexity that parallel evolution would be unparsimonious.

Reduced postorbitals are also found in some testudinids and pleurodires but have been acquired independently in these taxa. An elongate (primitive, but often laterally reduced) postorbital is found in all chelydrids, some testudinids (e.g. Chrysemys scripta), in most other cryptodires, and in some pleurodires. A reduced neural series is characteristic of most pleurodires but is also assumed to be convergent since some primitive pleurodires have a complete series of neurals (e.g. Platychelys). The absence of a biconvex 4th cervical centrum is presumed to be primitive for turtles.

The Chelonioidea as defined by Gaffney (1975a, p. 418, 428) excludes the more primitive members which Gaffney places in this group, the Plesiochelyidae. A more thorough, derived character analysis which attempts to incorporate these turtles is given by Gaffney (1976), who concludes that all chelonioids have a high dorsum sellae, not overhanging the sella turcica as in testudinoids, and which bears a prominent sagittal ridge. An examination of the dorsum sellae of other reptiles reveals that crocodiles, many lizards, some dinosaurs, and Captorhinus also have a high, ncn-overlapping dorsum sellae. DeBeer (1937, p. 256) notes that the dorsum sellae is high in early embryos of Emys. This structure even bears a sagittal ridge in Captorhinus (see Fox and Bowman, 1966). My initial reaction to these comparisons was to consider the high dorsum sellae of chelo- 
nioids as a primitive feature shared by the reptiles cited, but the presence of the low dorsum sellae in baenoids, testudinoids and pleurodires indicates, in the absence of other evidence, that the common ancestor of cryptodires and pleurodires possessed a low dorsum sellae and that the chelonioid structure is a shared, derived character. A discovery that some primitive cryptodires or pleurodires have a high dorsum sellae would refute this hypothesis and support the view that these groups reduced the dorsum sellae independently. Other derived characters in the braincase and forelimbs are shared by the advanced chelonioid taxa, including the Toxochelyidae, to which chelydrids have been allied by some observers (Hay, 1908, p. 27; Zangerl, 1953, p. 267).

The testudinoids form a homogenous group for which I can hypothesize only a single, weak synapomorphy, the biconvex 4 th cervical vertebra. Characters which may relate them to other turtles include: 1) the biconvex 4th cervical vertebra-absent in primitive baenoids and "trionychoids," present in all chelonioids in which cervicals are known; 2) loss of mesoplastra-mesoplastra present in baenoids, lost in all other cryptodires; 3) loss of nasal bones-nasals present in primitive baenoids and primitive cheloniods, absent in trionychoids and testudinoids, 4) emargination of temporal region of skull-skull roof well developed in Proganochelys, baenoids and chelonioids (except for Corsochelys), emarginate in all testudinoids and trionychoids, except Macroclemys and Platysternon. I suggest that testudinoids and trionychoids form a monophyletic group sharing relatively great temporal emargination and loss of nasal bones, and that their most immediate common ancestor lacked a biconvex 4th cervical. A biconvex 4th cervical is hypothesized to have been independently derived by testudinoids, some baenids and chelonioids. This is not yet a convincing argument, since it is based on characters that seem to be "easily" acquired, but I propose it as a testable hypothesis.

Monophyletic groups within the Testudinoidea may be proposed as shown in figure
4. The Chelydridae, including Emarginachelys, Chelydra, Protochelydra and Macroclemys, are diagnosed by derived characters as discussed below. Testudinids (sensu Romer, 1956) share two, biconvex cervical vertebrae (Williams, 1950), a character not found in other cryptodires, except Neurankylus (see Wiman, 1933). Within the Testudinidae, only Platysternon and the Emydinae (of McDowell, 1964) have a double articulation between the 5 th and 6 th cervical centra. The Emydinae are further characterized by the loss of the "batagurine" process and, in more advanced genera, by the reduction of the pterygoid. As a group, the Batagurinae are diagnosed only by primitive characters, although monophyletic complexes occur within the subfamily as defined by McDowell. Advanced testudines share a number of derived characters including: 1) a high, convex shell; 2) alternate constriction and expansion of the costals; 3 ) thickened epiplastra; 4) expanded coracoid; 5) reduction of phalangeal number; 6) fusion of ventral margins of femoral trochanters; 7) contact of quadrate posterior to incisura collumella auris; 8) depression of the palate in ventral view; 9) ventral processes of the prefrontals far apart (Loveridge and Williams, 1957; Auffenberg, 1974). Many of

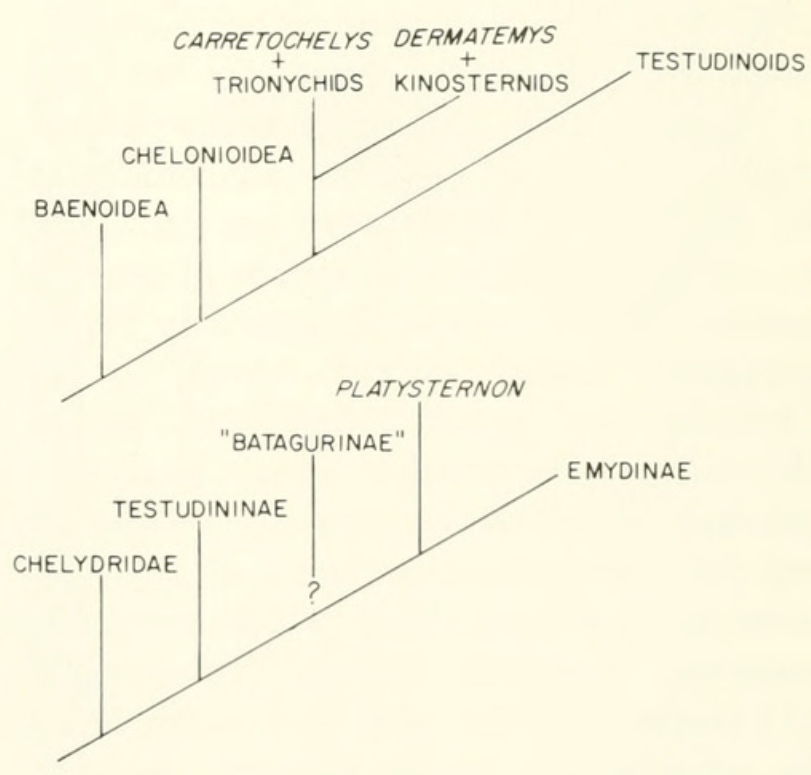

FIG. 4. Hypothesized phylogeny of cryptodiran turtles (top) and testudinoids (below). 
these characters are absent in the more primitive living and fossil taxa currently assigned to this group and Auffenberg (1974) suggests that some of the characters may have evolved several times.

In the following discussions, comparisons with baenids and plesiochelyids are based on Gaffney's (1972a, 1976) descriptions and figures unless otherwise noted. Comparisons with Protochelydra are based on Erickson's (1973) figures and tables. Terminology of cranial structures follows Parsons and Williams (1961) as illustrated by Gaffney (1972b).

\section{SYSTEMATIC DESCRIPTION}

\author{
Superfamily TESTUDINOIDEA \\ Family CHELYDRIDAE \\ Genus EMARGINACHELYS n. gen.
}

Type species.-Emarginachelys cretacea $\mathrm{n}$. sp.

Diagnosis.-Cryptodiran turtle with processus trochlearis oticum and pterygoid brace to the braincase; foramen stapedio-temporale not reduced; nasal bones absent; prefrontals downturned anteriorly; frontals bordering the orbits; the skull roof narrowed above the orbits; otic bridge broad; supraoccipital crest long and low; jugal and postorbital bones elongate; premaxillary "hook" absent; quadrate open behind the stapes; cheek region with some lateral emargination; foramen posterior canalis carotici interni not bordered by basisphenoid; foramen carotico-pharyngeale not enlarged; fossa for attachment of the pterygoideus musculature not extending far anteriorly; triturating surface of maxilla narrow, with a prominent secondary ridge; pterygoid "waist" neither broad, as in Chelydra, nor greatly constricted, as in Macroclemys temminckii; vomer contacting palatines posteriorly; foramen nervi trigemini and foramen cavernosum small, situated anterior to the dorsum sellae; prootic contacting processus clinoideus laterally; epipterygoid (?) absent; dorsum sellae low, overhanging the sellae turcica; neither foramen caroticum laterale nor foramen anterior canalis carotici interni enlarged; one biconvex cervical ver- tebra; costal bones not meeting behind the neurals; no serration of the carapace posteriorly; supramarginal scutes absent; carapace weakly keeled medially, costals with parallel ridges; peripherals unsculptured; no carapacial fontanelles; nuchal bone with long, costiform processes; plastron cruciform, ligamentously attached to the carapace; entoplastron reduced, but not "T" shaped; right and left sides of plastron in contact, but not sutured together; thecal process on the ilium; pectineal processes of the pubis not laterally expanded; pubis and ischium separated medially.

\section{EMARGINACHELYS CRETACEA n. sp.}

Diagnosis.-Same as for the genus.

Holotype.-KUVP 23488: carapace; plastron; skull lacking lower jaw; right stapes, posterior horn of hyoid; right forelimb and girdle lacking phalanges of digits IV and V; left forelimb and girdle lacking pisiform and distal half of metacarpal $\mathrm{V}$; left hindlimb and girdle lacking most of digits $\mathrm{I}$ and $\mathrm{V}$ and the distal phalanx of digit IV; right ilium; cervicals 3-7; anterior half of cervical 8; caudals 1-3.

Horizon and Type Locality.-Hell Creek Formation (Upper Cretaceous); Garfield County, Montana; SW 1/4 NW 1/4 S. 35, T. 21 N., R. 37 E.

\section{MORPHOLOGIC AND COMPARATIVE DESCRIPTION}

Skull, Dorsal View (Fig. 5, 6).-The skull roof is composed of the frontal, prefrontal, parietal, and postorbital bones. Nasal bones are absent. The prefrontals are strongly downturned anteriorly, unlike Chelydra and Macroclemys. The descending process of the prefrontal forms the anterior wall of the fossa orbitalis and the posterior wall of the fossa nasalis. The dorsal portion of the fissura ethmoidalis is not broadly expanded as in testudines or Adocus, but resembles the condition in Chelydra and emydines. The foramen supraorbitale is preserved on the right side and is indistinguishable from that of Chelydra. 


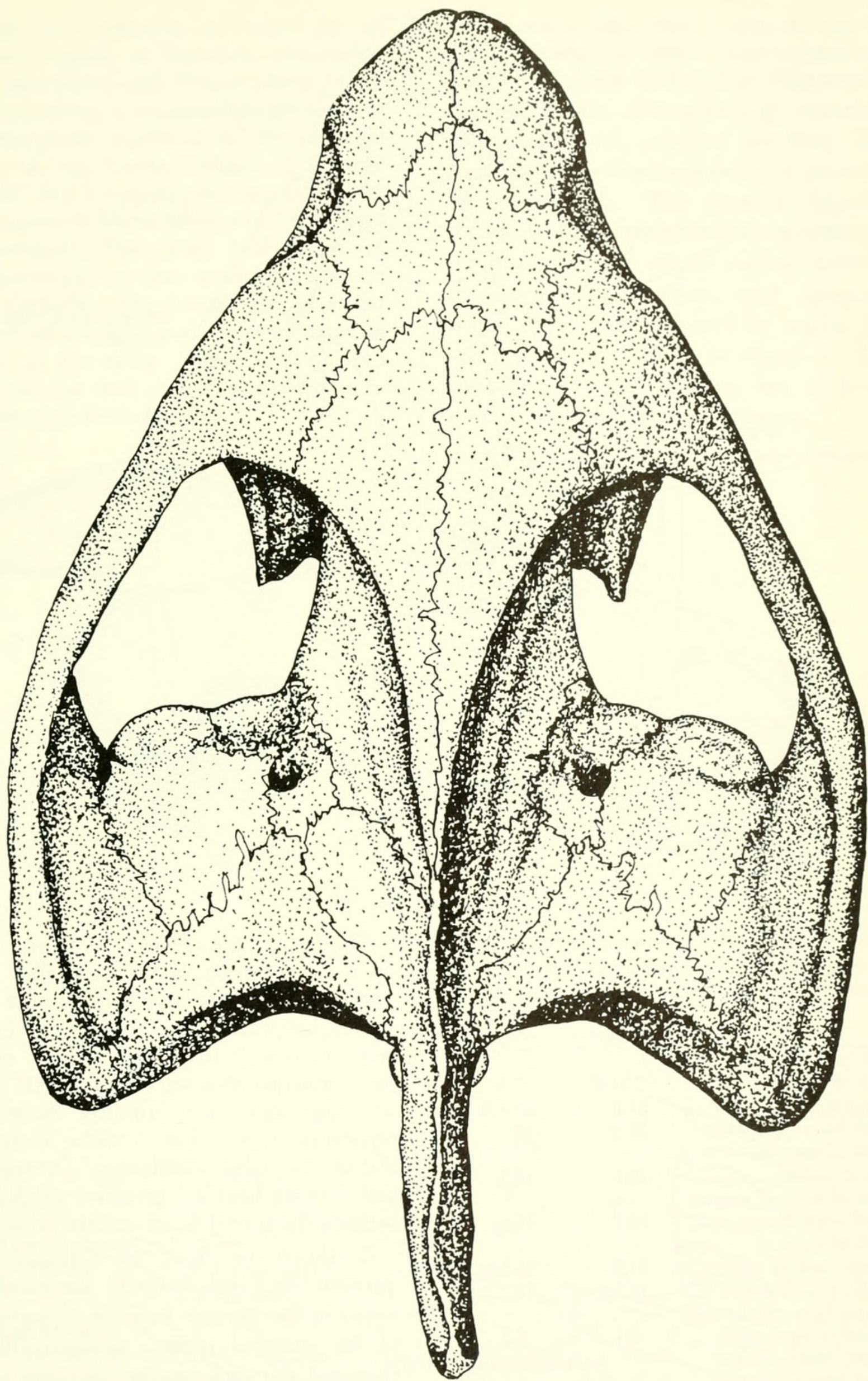

FIG. 5. Emarginachelys cretacea (KUVP 23488), restoration of skull in dorsal view. Skull length (condyle to tip of snout) is $77 \mathrm{~mm}$. 


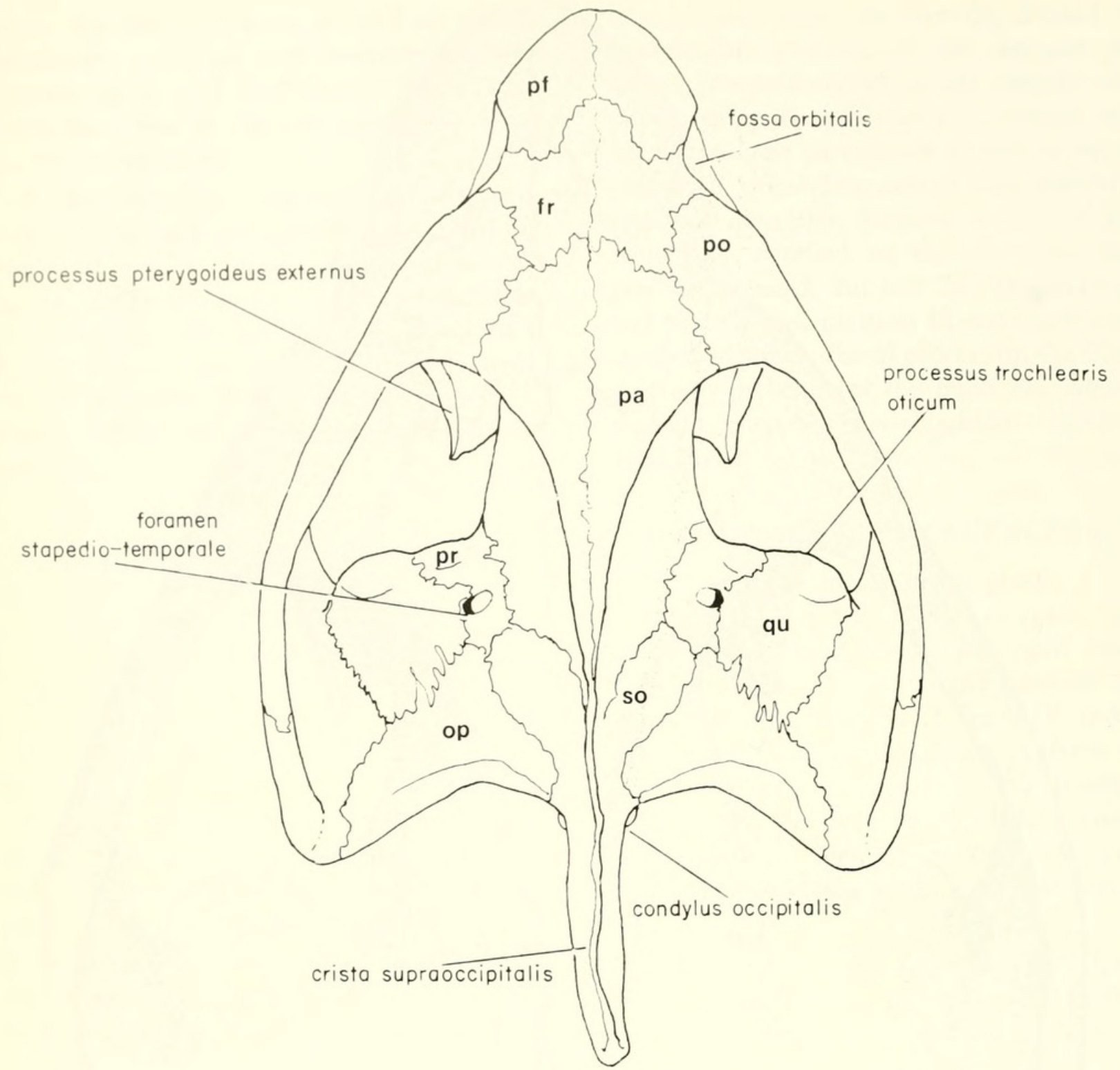

Fig. 6. Key to Figure 5.

TABle 1: Skull Measurements for Holotypes of Emarginachelys and Protochelydra.

\begin{tabular}{|c|c|c|}
\hline & $\begin{array}{l}\text { Emargi- } \\
\text { nachelys }\end{array}$ & $\begin{array}{l}\text { Proto- } \\
\text { chelydra }\end{array}$ \\
\hline $\begin{array}{l}\text { Skull length (condyle } \\
\text { to tip of snout) }\end{array}$ & $77.1 \mathrm{~mm}$ & 77.8 \\
\hline Maximum skull width .... & 57.0 & $69.8 \pm$ \\
\hline $\begin{array}{l}\text { Width across quadrates .. } \\
\text { Width of posterior }\end{array}$ & $52 \pm$ & 68 \\
\hline 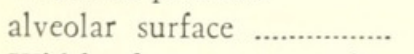 & 10.1 & 16.5 \\
\hline $\begin{array}{l}\text { Width of snout at anterior } \\
\text { end of orbit ..................... } \\
\text { Width of snout at }\end{array}$ & 18.7 & $20 \pm$ \\
\hline posterior end of orbit ....... & 31.2 & $38.2 \pm$ \\
\hline $\begin{array}{l}\text { Anterior snout height .... } \\
\text { Distance from anterior wall }\end{array}$ & $13.5 \pm$ & 14 \\
\hline $\begin{array}{l}\text { of orbit to nasal notch .... } \\
\text { Distance from posterior } \\
\text { rim of orbit to anterior } \\
\text { margin of temporal }\end{array}$ & 6.4 & 6.2 \\
\hline emargination & 11.4 & 15.7 \\
\hline
\end{tabular}

The frontals are relatively large and make up a large portion of the skull roof. The prefrontal and postorbital bones do not meet above the orbits. This allows the frontal bones to contact the dorsal margins of the fossa orbitalis. Contact of the frontal bones with the orbits is a primitive feature for cryptodires that is lost in other chelydrids and in some other testudinoids. Dermatemys and Trionyx have the primitive relationship between the frontal bones and the orbit.

Compared to those of Chelydra, the parietals of Emarginachelys are much reduced by the extreme posterior emargination of the temporal region. Gaffney (1975b) theorized that such emargination was primitive for the Chelydridae. The fully-roofed condition, is however, almost certainly primi- 
tive for the Cryptodira as judged by the temporal regions of baenoids, chelonioids, some pleurodires, and Proganochelys. Gaffney's hypothesis is supported by presence of the emarginate condition in the temporal region of the Upper Cretaceous Emarginachelys, and I interpret the expanded temporal region of Macroclemys as an evolutionary reversal. The skull roof bones of Emarginachelys are not strongly sculptured as in Chelydra. The frontals extend as far forward on the skull midline as the anterior margin of the orbits. Above and between the orbits, the skull roof is constricted as in Chelydra and Protochelydra.
The otic bridge, which covers the otic region dorsally, is longer antero-posteriorly than in any other chelydrid or Platysternon. In this respect, Emarginachelys resembles trionychoids and primitive emydines, and I assume that a broad otic bridge is primitive for testudinoids. The foramen stapediotemporale is situated between the prootic and the quadrate. The sutural contacts between the squamosal, quadrate, and opisthotic bones are partially obscured by cracks, but are interpreted to be as in Figure 6. The supraoccipital crest is long, but is lower than in Chelydra or Macroclemys.
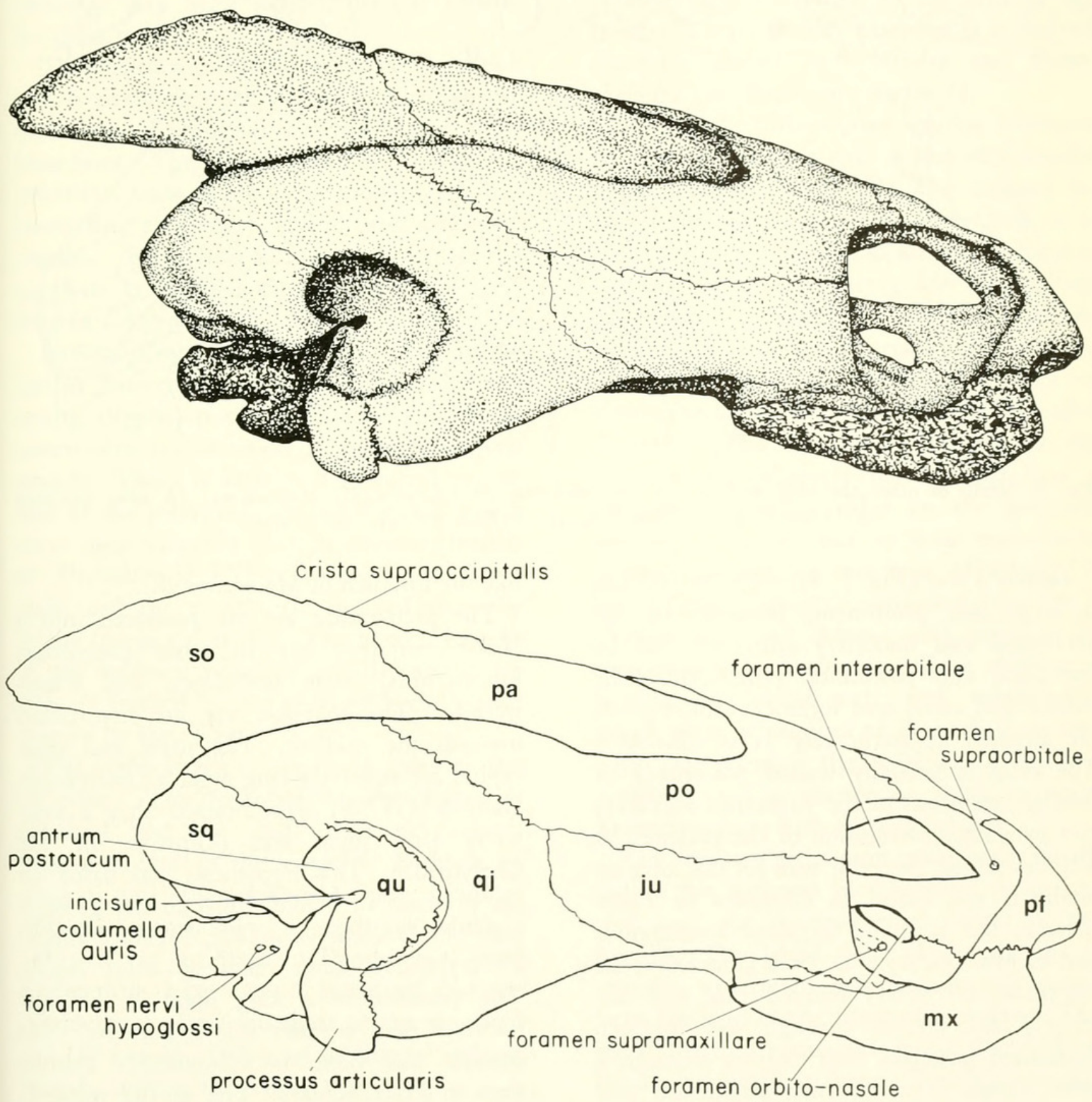

Fig. 7, 8. Fig. 7-Restoration of skull in lateral view. Skull length is $77 \mathrm{~mm}$. Fig. 8-Key to Figure 7. 

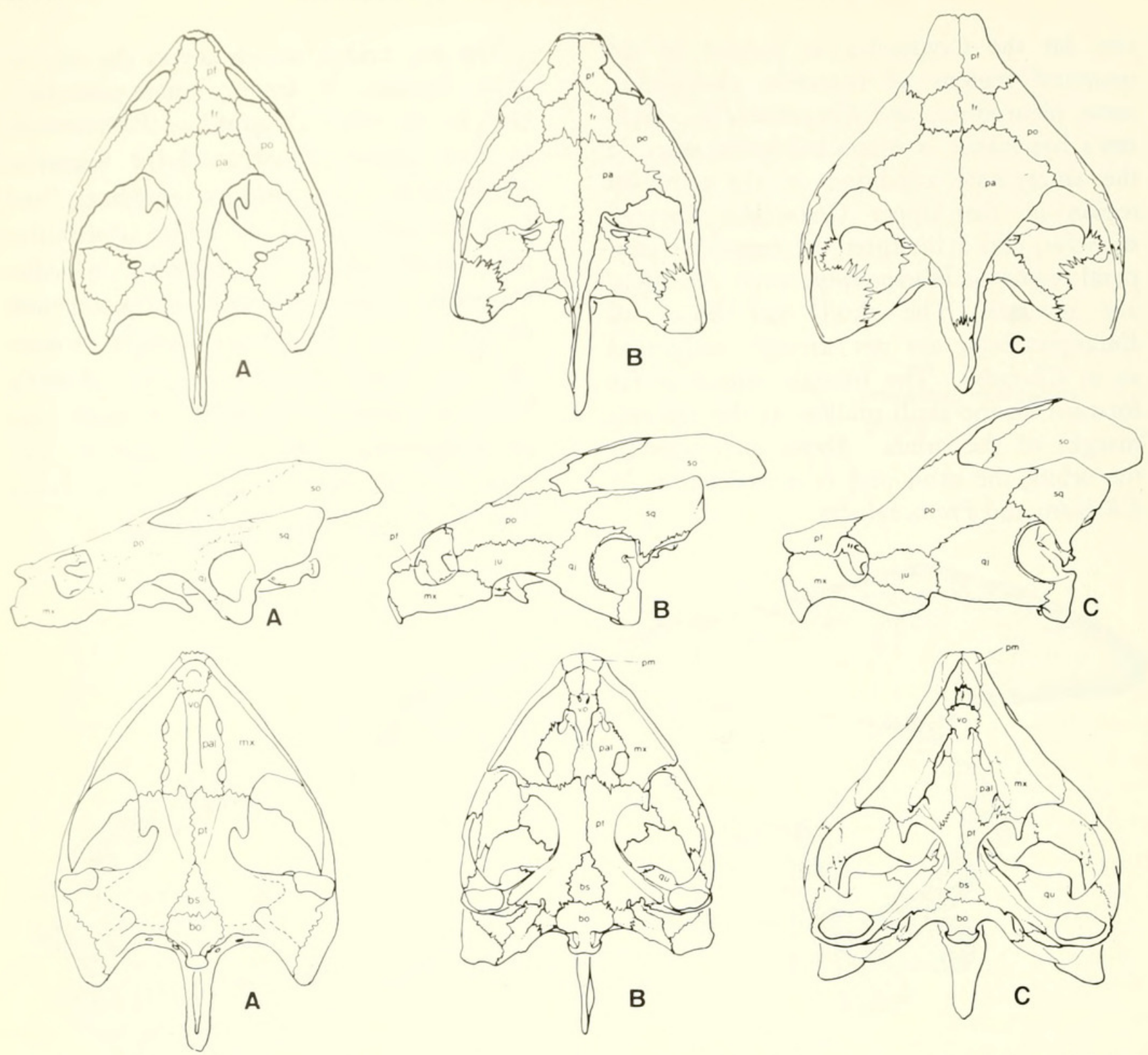

Fig. 9. Skulls of other chelydrid turtles: A) Protochelydra, B) Chelydra, C) Macroclemys (A after Erickson 1973 and Gaffney 1975b; B, C after Gaffney 1975b). Not to scale.

Lateral View (Fig. 7, 8).-The orbital rim is large and prominent, bounded by the prefrontal and maxillary anteriorly and by the jugal and postorbital posteriorly. The infraorbital canal and foramen orbital-nasale are situated approximately as in Chelydra. The orbit is partially walled posteriorly by medial extensions of the jugal and maxillary and by a lateral extension of the palatine. A well-developed, posterior wall for the fossa orbitalis is not found in Chelydra or Platysternon, but is found in some kinosternids and in Macroclemys. In Emarginachelys, the inframaxillary artery entered this wall anteriorly and exited through the foramen palatinum posterius after passing through a short canal. The foramen palatinum posterius is small, unlike that of Chelydra, but like the foramen of Macroclemys.

The premaxillae are not produced into a "hook" as they are in other chelydrids, kinosternids, some testudines, and Platysternon. The maxillae are not constricted towards the midline. The jugal and postorbital are relatively long as in all chelydrids. Gaffney (1975b) hypothesized that a relatively long jugal was primitive for the Chelydridae. This hypothesis was based on the presence of a long jugal in the geologically old Protochelydra (Fig. 9), since almost all cryptodires have relatively short jugals. The presence of a long jugal in Emarginachelys does support this hypothesis, even though this bone is substantially shorter than in Protochelydra. The shorter jugal in Macroclemys temminckii is interpreted as a 
reversal. The postorbital bone is long in chelonioids, baenoids, and chelydrids and this condition is probably primitive for cryptodires. In the "cheek" region, Emargi. nachelys is only slightly emarginate, unlike Protochelydra and Chelydra, but similar to Macroclemys. This does not support Gaffney's (1975b) hypothesis of a primitively emarginate cheek region for chelydrids. The weakly emarginate condition also occurs in the primitive baenoids, Trinitichelys and Naomichelys, and in Platysternon, Damonia, Proganochelys, Desmatochelys and cheloniids. I suggest that the relatively-great, lateral emargination of Chelydra and Protochelydra may be a shared, derived feature for these turtles.

The incisura columella auris of the quadrate is narrowly open posteriorly, unlike the quadrates of all other chelydrids and most testudines. The open condition is probably primitive, since it occurs in most cryptodires (including emydines), and in most sauropsid reptiles. The processus articularis of the quadrate is much shorter in Emarginachelys than in Chelydra.

Ventral View (Fig. 10, 11).-The tuberculum basioccipitale is accentuated by the strong depression of the basioccipital to accommodate the insertion of the rectus capitis muscle. There is little postero-lateral expansion of the pterygoid, leaving the otic region more open ventrally than in other chelydrids or Dermatemys. The processus interfenestralis and the prootic are exposed ventrally in the fenestra postotica. The ventral margin of the foramen posterior canalis carotici interni is formed by the pterygoid; the dorsal margin by the prootic.

The right stapes is preserved more or less in place. The footplate of the stapes is flattened and the shaft does not extend from the center of the footplate. Both plesiochelyids and other chelydrids have a similar stapedial morphology, a condition which I interpret as primitive. Dermatemys and kinosternids have conical footplates that are symmetrical about the shaft of the stapeidal rod (McDowell, 1961), an additional synapomorphy uniting these taxa.

The ventral surface of the basisphenoid extends only slightly beyond the mandibular condyles anteriorly, as in Protochelydra and some emydines. Macroclemys, Chelydra, baenids and plesiochelyids generally have the basisphenoid extending farther beyond the mandibular condyles. I am uncertain which condition is primitive for testudinoids. On the pterygoid brace to the braincase, lateral to the basisphenoid and posterior to the fossa temporalis inferior, are depressions for the attachment of the pterygoideus musculature like that of many emydines (e.g. Graptemys), Macroclemys, baenids, and plesiochelyids. I suggest that a posterior depression for the pterygoideus musculature is primitive and that the extension of the depressed surface anterior to the area of the processus pterygoideus externus is a derived character shared by Chelydra and Protochelydra (see Erickson's figure 1).

The skull of Emarginachelys is narrower in many proportions than is that of Chelydra (compare Figs. 9 and 10). The distance between the quadrates is relatively less, as is the width of the pterygoid waist, the distance between the processi pterygoidei externi, and the distance between the postero-medial margins of the triturating surfaces of the upper jaws. The processi pterygoidei externi of Emarginachelys are only slightly extended ventrally. The triturating surfaces of the maxillae are relatively narrow and bear a pronounced median ridge on the posterior portion, similar to that of some testudinids. Among cryptodires, this type of ridging is found only in some testudinids (sensu lato), Dermatemys, and Adocus, and seems to be correlated with herbivory. Since ridging is lacking in kinosternids and trionychids, which share a number of derived characters with Dermatemys, the presence of midline maxillary ridges cannot be used to unite Emarginachelys with dermatemydids.

The foramen palatinum posterius is small, unlike this foramen in Chelydra. It is situated near the postero-medial corner of the maxilla. The labial ridge of the maxilla is straight, unserrated and prominently raised from the level of the triturating surface. The labial ridge is continued across the midline by the premaxillary bone. There is no premaxillary "hook," a derived feature shared by other chelydrids, and no median recess 


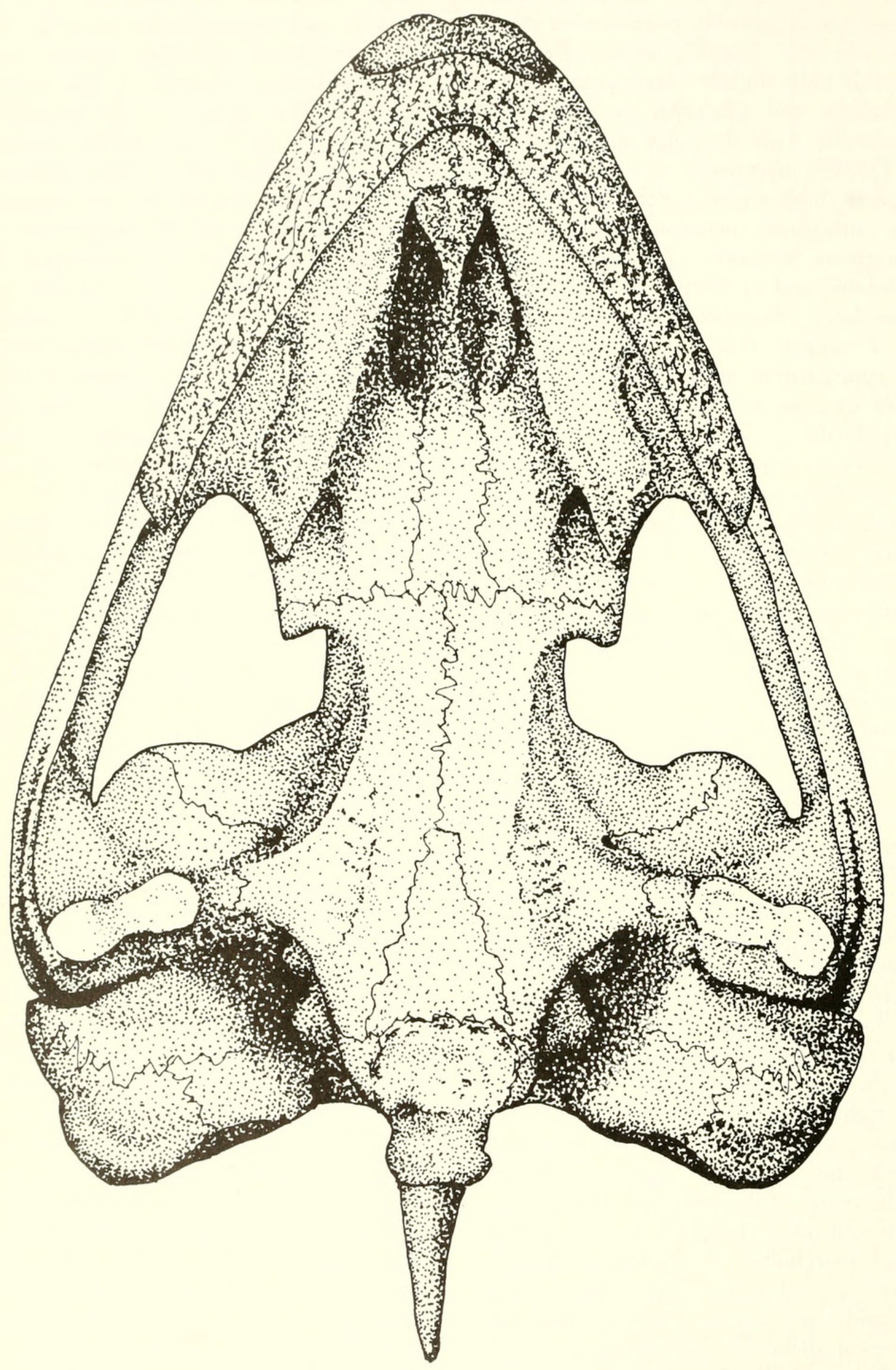

FIG. 10. Restoration of skull in ventral view. Same scale as Figure 5. 


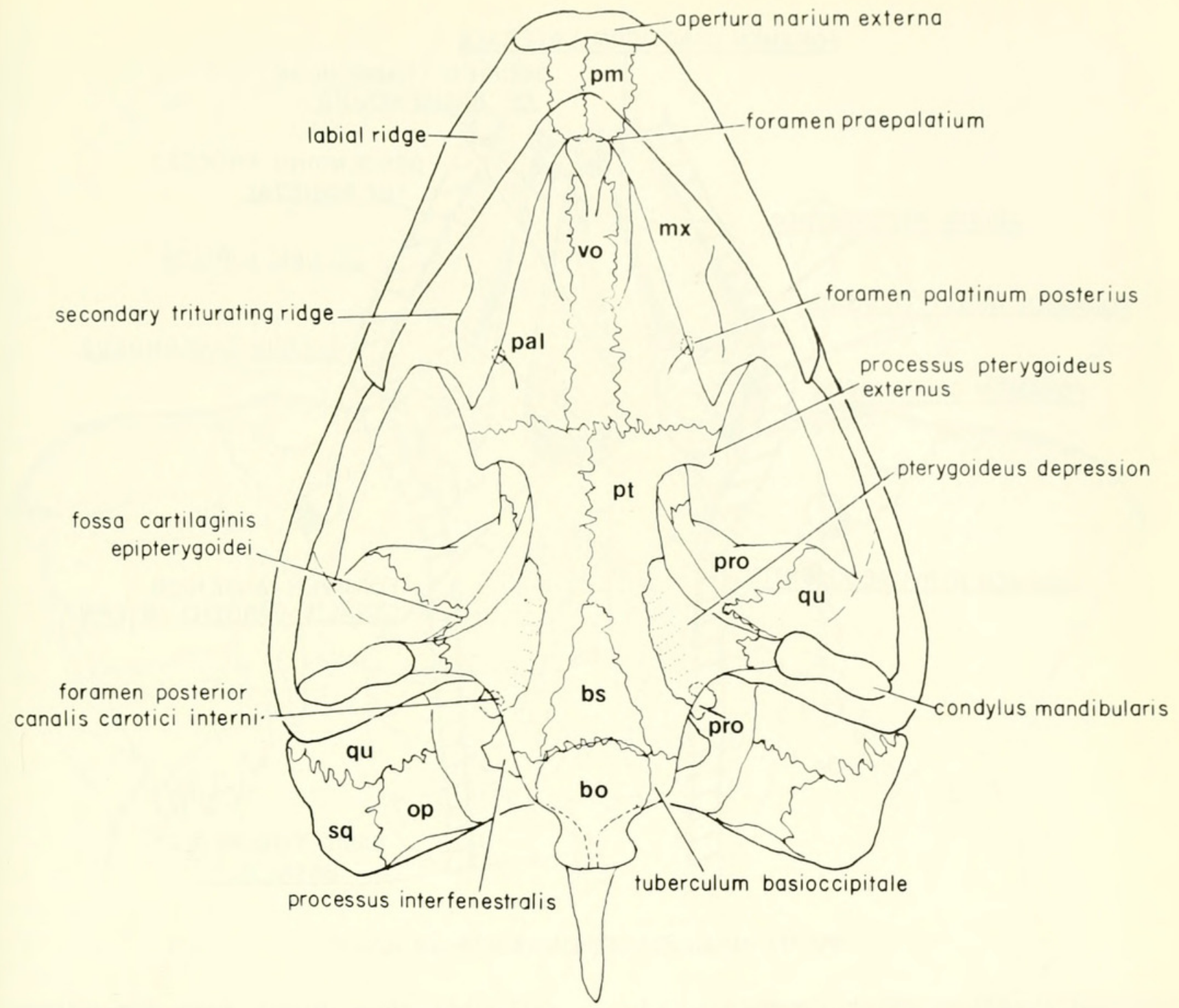

FIG. 11. Key to Figure 10.

exists in the premaxillary. A median recess is present on premaxillae of emydines and batagurines. The triturating surface of the maxilla narrows anteriorly and terminates at the sutural contact between the vomer and the maxilla. The vomer and premaxillae bear the paired foramina praepalatina. As in all chelydrids, the vomer contacts the palatines posteriorly and is not crested ventrally.

Braincase (Fig. 12).-The parietals form most of the side wall of the braincase. The foramen nervi trigemini is small and is situated dorsal and anterior to the dorsum sellae. Its margins are formed mostly by the prootic internally and mostly by the parietal externally. There is a distinct fossa cartilaginis epipterygoidei, but there appears to be no independently ossified epipterygoid. It is also possible that I have incorrectly interpreted, as cracks, the sutures which delimit this bone. The quadrate is narrowly excluded from the foramen nervi trigemini, but forms the posterior border of the fossa cartilaginis epipterygoidei. The descending processes of the parietals are broad. In this respect and in the dorsal position of the foramen nervi trigemini, Emarginachelys resembles Dermatemys and is unlike Chelydra and Macroclemys.

The structure of the floor of the braincase is difficult to interpret, due to both its uniqueness and to post-mortem damage. The left side of the braincase anterior to the dorsum sellae is considerably crushed and the right side posterior to the dorsum sellae has been damaged by root growth into the skull. The foramen cavernosum is situated anterior to the dorsum sellae, just ventral to the trigeminal foramen. The anterior placement of the foramen cavernosum is, to my knowledge, unique among turtles. The situation is apparently the result of the union of the 


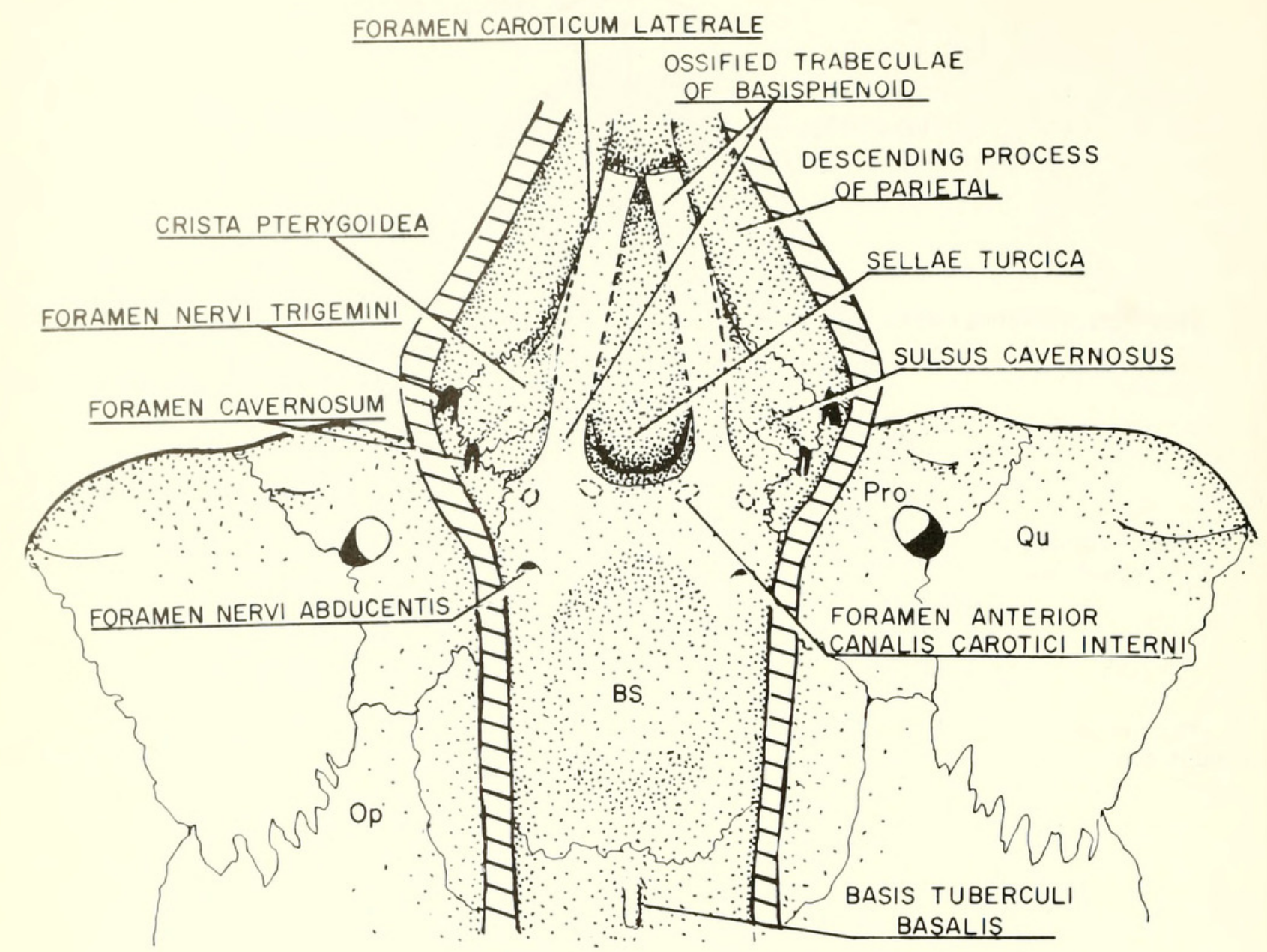

FIg. 12. Restoration of braincase in dorsal view.

processus clinoideus with the prootic which is anteriorly expanded medial and dorsal to the area normally occupied by the sulcus cavernosus. The dorsum sellae is low and overlaps the floor of the sellae turcica. The anterior internal carotid foramina are situated beneath the shelf of the dorsum sellae and are closer together than in Chelydra. Part of the trabecula of the right side is preserved; beneath it the lateral carotid foramina can be located with probes. They are close in size to the anterior internal carotid foramina, but direct measurement is impossible. The crista pterygoidei is short and bears the sulcus cavernosus as it rises toward the foramen cavernosum.

Cervical Vertebrae.-Most of the third through eighth cervical vertebrae are preserved. The cervical, central articulations may be represented by Walther's (1922) formula as $(3(4) 5) 678$. This is comparable to the cervical central pattern of Macroclemys and Chelydra. With only rare exceptions, these turtles have the patterns $(2(3(4) 5) 6) 7) 8)$ and $(2(3(4) 5) 678)$ (Williams, 1950). The eighth cervical of Emarginachelys is not biconvex as in emydines, batagurines, testudines, and Platysternon. A biconvex, fourth cervical is a derived character which occurs only in some eucryptodires (sensu Gaffney), with the possible exception of Neurankylus. The cervical centra of Emarginachelys are much shorter than those of recent chelydrids with a comparably sized carapace. Otherwise the centra are morphologically similar to those of Chelydra and Macroclemys.

Carapace and Plastron (Fig. 13).-The carapace and plastron of Emarginachelys shows features absent in other chelydrids. The bones of the carapace are thick, especially the neurals and peripherals. There is no emargination anteriorly and scalloping posteriorly. There are 11 pairs of peripherals, 8 pairs of costals, 8 neurals, 2 suprapygals, and one nuchal. The neurals are longer than 

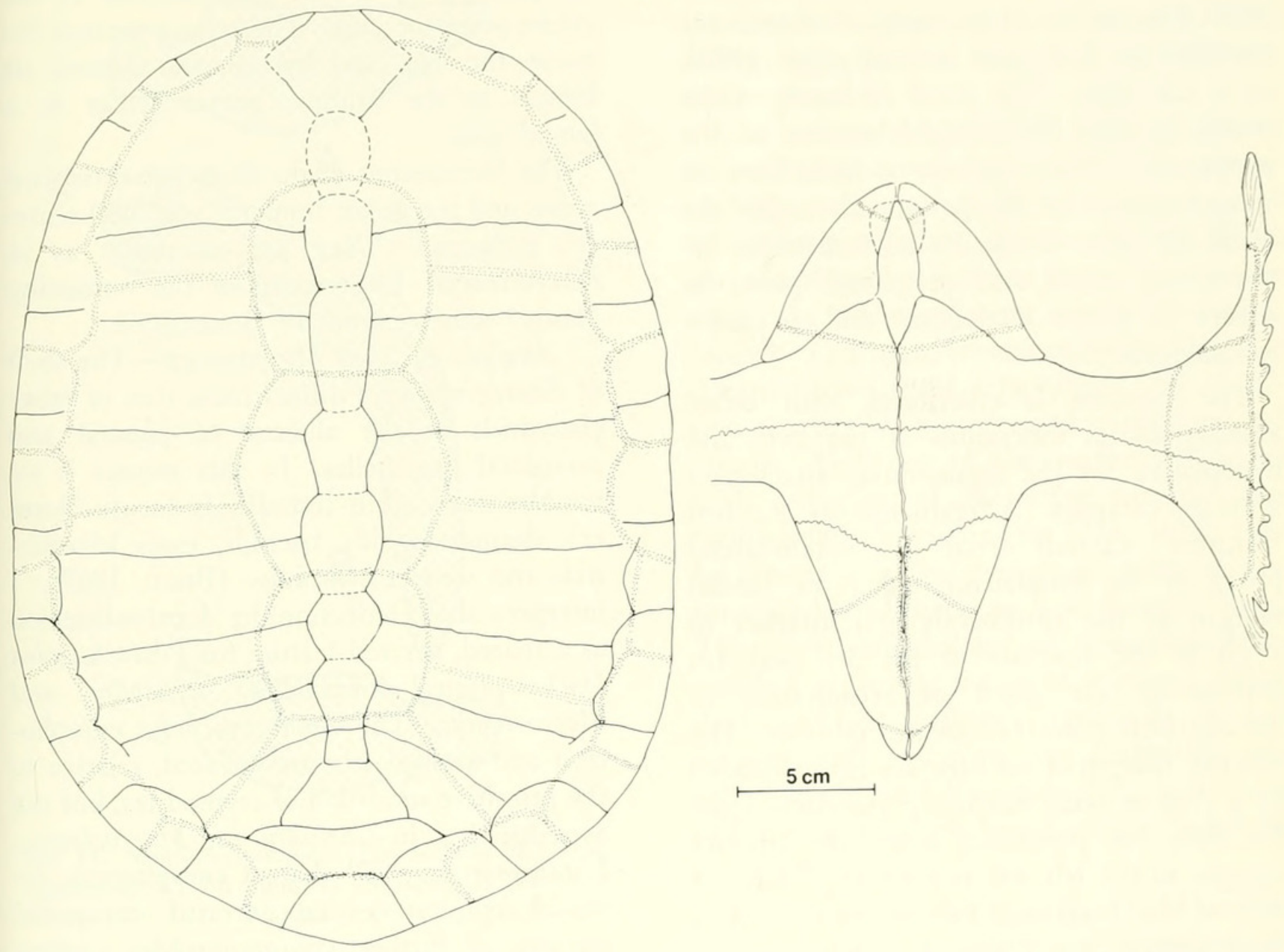

FIG. 13. Partial restoration of carapace and plastron.

wide and narrow sharply anteriorly. The impression of the most anterior vertebral scute cannot be discerned. The impressions of the remaining vertebrals are about as wide as they are long and approximately square in outline. There are no supramarginal scutes as are found in Macroclemys temminckii.

A low, median keel extends from the 4th neural posteriorly to the base of the posterior suprapygal. Auxillary ridges extend from the posterior of the 4 th through 7 th neurals and diverge anteriorly and laterally, terminating after a short distance. Costals 5 and 6 , on the inferior half, and costals 4 and 5, on the superior half, are strongly sculptured with parallel ridges similar to the costal sculpture of Pseudemys. Costals with similar sculpture from the Upper Cretaceous Lance Formation were described by Estes (1964). These may belong to Emarginachelys, rather than to Neurankylus as suggested by Gaffney (1972a). There is no sculpture on the peripherals. Cross sections of several periph- erals are shown in Figure 14. Peripherals 4,5 and 6 are elongated in the ventral direction for the attachment of the plastron. There is a lateral "keel" on these peripherals that merges on peripherals 3 and 7 with the ventral margin of the carapace. Pits in the ventromedial margins of the peripherals are directed inward and downward for reception of the digitate lateral projections of the plastron. The 4th and 7th peripherals are the more deeply pitted while the 5 th and 6 th are shallowly pitted at the ventro-medial margin. The posterior peripherals are tapered as in Dermatemys.

The broad prezygapophyses of the first dorsal vertebra curve downward and outward to allow vertical flexure of the neck. The ventral surfaces of the succeeding dorsal vertebrae are not flattened as in Chelydra. The $2 \mathrm{nd}, 3 \mathrm{rd}$, and 4 th dorsals are ventrally keeled as in Dermatemys, but the more posterior dorsals are ventrally rounded. The 9 th and 10th dorsals are procoelous, the 10 th 
strongly so. The ribs of the 10 th dorsal are free. Ribs of the three sacral vertebrae are modified for a support for the pelvic girdle, as in Chelydra. The distal rib-heads of the costals fit into " $V$ " shaped notches in the peripherals. There appears to have been no ventral closure of the peripherals under the distal rib ends. There are no fontanelles between the costal and peripheral plates as occurs in other chelydrids and in some toxochelyids.

The plastron is cruciform, with broad antero-posterior extensions of the hyo- and hypoplastra for the ligamentous attachment with the carapace. A ligamentously attached "buttress" extends from the antero-lateral prong of the hyoplastron along the medial margin of the peripherals and attaches in a pit at the juncture of the 3rd and 4th peripherals, the point of termination of the costiform process of the nuchal bone. The anterior margin of the carapace is thus braced by a ring of bone extending anteriorly from the right 4 th peripheral across the anterior margin to the left 4 th peripheral. I am not sure of the functional advantages of such a bony support, but I suspect that it is associated with the reduced, ligamentously attached plastron in a heavy bodied, semi-aquatic turtle.

The entoplastron is not " $T$ " shaped as in other chelydrids, but is roughly triangular in outline, with a narrowly tapered posterior tip. It is articulated to the surrounding plastral bones by a kinetic squamous articulation (Fig. 13). Some of the anterior portion of the entoplastron extends laterally over the dorsal surface of the epiplastra and is not visible in ventral view (Fig. 13). The hyoand hypoplastra are strongly sutured together with most of the plastral bridge being formed by the hyoplastron. The epiplastra are broad compared to those of other chelydrids. The epiplastra articulate with the hyoplastra by convexo-concave "joints" and the right and left epiplastra do not suture together at the midline. The remaining plastral elements articulate with their counterparts of the other side in a loose kinetic articulation. This plastral morphology is unique and highly derived, differing from that of sea turtles. Plastral kinesis allowed free movement of the plastron by flexure perpendicular to the antero-posterior axis. The strong sutures between the hyo- and hypoplastra allowed no kinesis at the midline perpendicular to a lateral axis.

The impressions of the three inframarginal scutes and the gular, humeral, and anal scutes are preserved. They are essentially as in Macroclemys. Impressions of the remaining plastral scutes cannot be determined.

Analysis of Shell Morphology.-The shell of Emarginachelys differs from that of other chelydrids in the absence of plastral and carapacial fontanelles. In this respect it resembles most adult testudinids (sensu Romer), dermatemydids, baenids, some kinosternids and some Plesiochelys (Bram, 1965). I interpret shell reduction by fontanellization as a shared, derived feature for Protochelydra (lacks plastral fontanelles), Chelydra, and Macroclemys. The Emarginachelys entoplastron and xiphiplastra are reduced, relative to the primitive condition of cryptodires, but not as reduced as in Chelydra and Macroclemys. I interpret the " $\mathrm{T}$ " shaped entoplastron, reduced epiplastra, and serrated carapacial margin as further synapomorphies uniting Protochelydra, Chelydra and Macroclemys and the further reduction of the xiphiplastra as derived features shared by Macroclemys and Chelydra. If Protochelydra and Chelydra share a common ancestor not shared by Macroclemys, as suggested here, then reduced xiphiplastra and plastral fontanelles would be hypothesized to be derived in parallel.

The cruciform plastron and long costiform processes on the nuchal bone are also found in kinosternids and are particularly well developed in Staurotypus. These features, plus the presence of a single, biconvex cervical vertebra, were used by Williams (1950, whose classification was followed by Romer, 1956) to unite chelydrids and kinosternids into a single family. Since these features are absent in Dermatemys, which shares a derived cranial artery pattern with kinosternids (McDowell, 1961; Albrecht, 1967; Gaffney, 1975a), I suggest that the costiform process and the cruciform plastron were independently derived in kinosternids and chelydrids. The 4th cervical is biconvex in chelydrids while other cervicals are bioconvex in kinosternids and Dermatemys. 


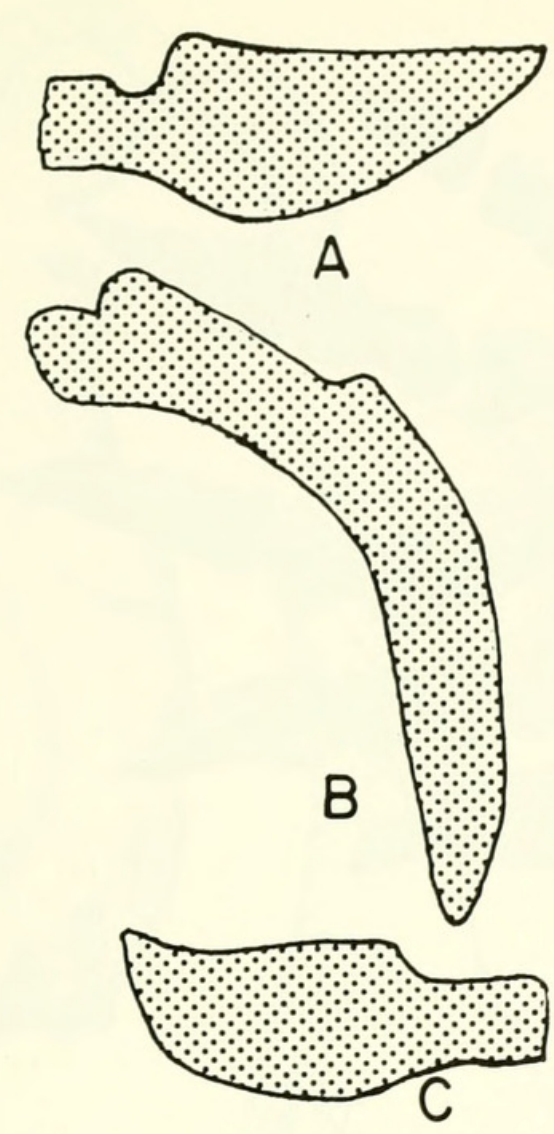

FIg. 14. Semi-diagrammatic cross sections of peripheral bones: A) 9 th right, B) 5 th right, C) 2 nd right. Natural size.

Plastral "buttresses," extensions of the plastron which suturally contact the costals, occur in many pleurodires, baenoids, dermatemydids, and testudinids and are assumed to be primitive for cryptodires. If the long, anterior extensions of the hyoplasta of Emarginachelys represent a reduced buttress, then the complete loss of a buttress would be a synapomorphy uniting other chelydrids. Ligamentous attachment of the plastron to the carapace is a derived feature found in all chelydrids, some emydines, Platysternon, and Claudius among non-chelonioid cryptodires. Since sutural attachment, the plesiomorphous condition, occurs in most testudinids (sensu lato), Dermatemys, and kinosternids, I regard ligamentous plastral attachment as examples of parallelism for chelydrids and these other taxa.

Shell morphology has been used (e.g. Hay, 1908; Zangerl, 1953) to suggest a close relationship for chelydrids and toxochelyids. These taxa share the cruciform plastron, "T" shaped entoplastron, ligamentous attachment of carapace to plastron, costo-peripheral fon- tanelles, and plastral fontanelles, all derived characters for cryptodires. Gaffney (1975a, 1976) suggests that this shell reduction is convergent.

The toxochelyid braincase indicates clearly the affinities of toxochelyids with the plesiochelyids and other chelonioids, as proposed by Gaffney. Derived features of the Toxochelys braincase which are shared by some, or all, of the chelonioids, but not by chelydrids, include: 1) a high, crested dorsum sellae that does not overlap the sella turcica (see discussion above); 2) approximated internal carotid arteries; 3) fusion of the ossified trabeculae with reduction of the sellae turcica. The taenia intertrabecularis (see Nick, 1912) may be present as a keel atop fused trabeculae of toxochelyids (Whetstone and Stewart, Ms.). The shell morphology of Emarginachelys, which I regard as the most primitive chelydrid, supports Gaffney's hypothesis of convergent shell reduction for chelydrids and toxochelyids, since Emarginachelys lacks most of the shell reduction found in later chelydrids or in toxochelyids.

Pectoral Appendages (Fig. 15, 16).-The left and right forelimbs are preserved essentially as they were articulated in life. The left forefoot lacks only the pisiform bone and the proximal half of the fifth metacarpal. Except for the structure of the intermedium, the morphology of the forelimb compares closely with that of adult chelydrids-the metatarsals and phalanges are relatively short and broad; the phalangeal formula is 2-3-33-3; the centralia are fused. The intermedium is wedge shaped, extending medially onto the distal surface of the radius (Fig. 15). To my knowledge, this carpal morphology is unique to Emarginachelys.

The humerus is similar to that of Chelydra. It is strongly "S" shaped, with the neck extending outward from the distal part of the shaft at an angle (angle "alpha" of Zangerl, 1953 ) of about 90 degrees. Its head is elliptical, with a prominent, lateral shoulder. The humeral shoulder of Chelydra and Protochelydra is poorly-defined while that of Macroclemys and Emarginachelys is prominent. There is a well-defined, intertrochanteric fossa immediately behind the head. The shaft of the humerus is massive, unlike the slender 

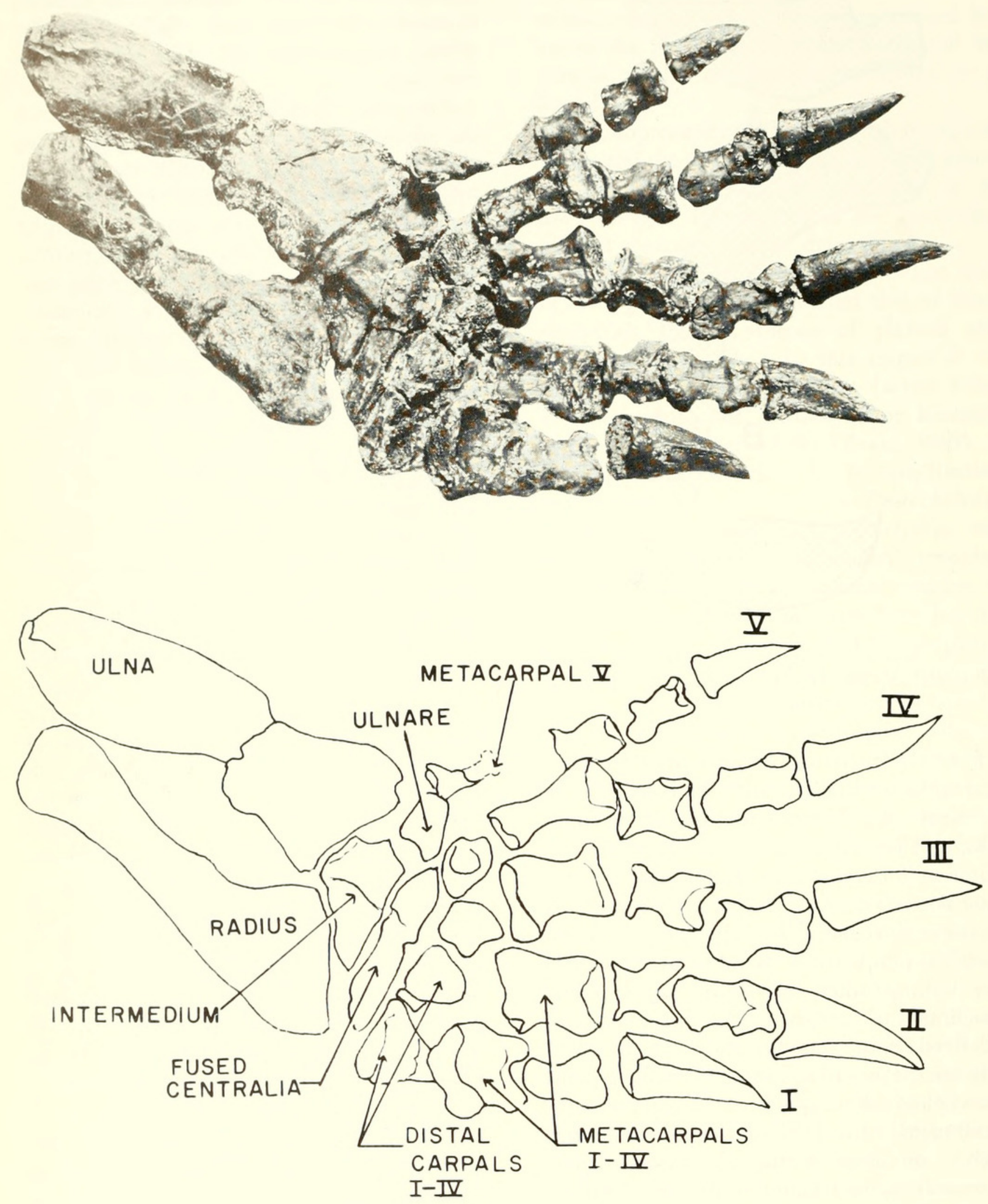

Fig. 15. Left forefoot, radius and ulna. Natural size.

humeri of emydines and Platysternon. Distally the shaft expands and bears two stout condyles.

Pectoral Girdle (Fig. 17)-As in all living turtles, the pectoral girdle is a three-pronged structure with postero-medial, medial and dorsal processes. The pectoral girdle compares closely with chelydrids except that the coracoid is less expanded than in Chelydra, and the ventro-medial process of the scapula is more massive.

Pelvic Appendages (Fig. 15, 18).-The left 

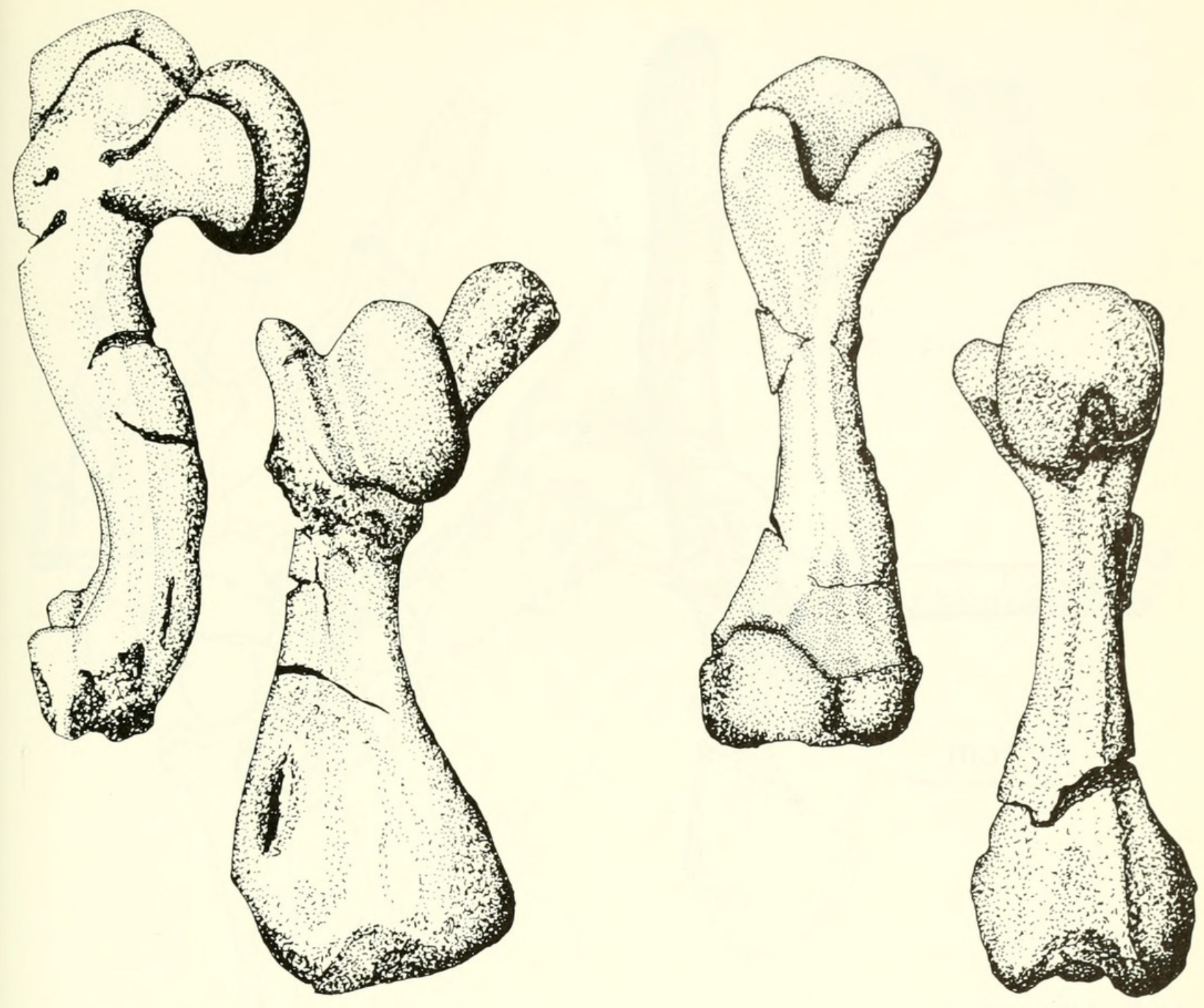

Fig. 16. Left-Lateral and dorsal aspect of left humerus; Right-Ventral and dorsal aspect of left femur. Natural size.

hind limb and the left half of the pelvic girdle are well preserved. The left foot lacks most of digits $\mathrm{I}$ and $\mathrm{V}$. As far as can be determined, the phalangeal formula is the same as in Chelydra. Of the tarsals, the astragalus and calcaneus are fused; a bump on the distal edge of the astragalus probably represents the fused centrale. The astragalus, calcaneus, and centrale are usually well fused in adult chelydrids, but are sometimes discernible or separate in juveniles (cf. Zug, 1971).

The femur is similar in size and general morphology to that of Chelydra. The femoral trochanters are more massive than those of Chelydra, with constriction of the intertrochanteric fossa. The fossa is partially enclosed ventrally by a low ridge which connects the distal borders of the trochanters. There is much greater curvature in the shaft than in Macroclemys or Chelydra. The distal con- dyles are strongly produced from the ventral surface.

Pelvic Girdle (Fig. 19).- The ilium is strongly inclined posteriorly; at the dorsal end it expands into a rugose surface which served for ligamentous attachment of the pelvis to the carapace. There is a well-developed, thecal process on the anterior margin. Among living cryptodires studied by Zug (1971), only kinosternids have the thecal process on the ilium. If the presence of this process is considered synapomorphous, Emarginachelys might be presumed to share a common ancestor with kinosternids and Dermatemys that is not shared by chelydrids. I do not accept this interpretation. As discussed above, the cranial circulation of Dermatemys and kinosternids is unique and presumably synapomorphous. If a close relationship with Emarginachelys exists, the Dermatemys ossified shell and the 


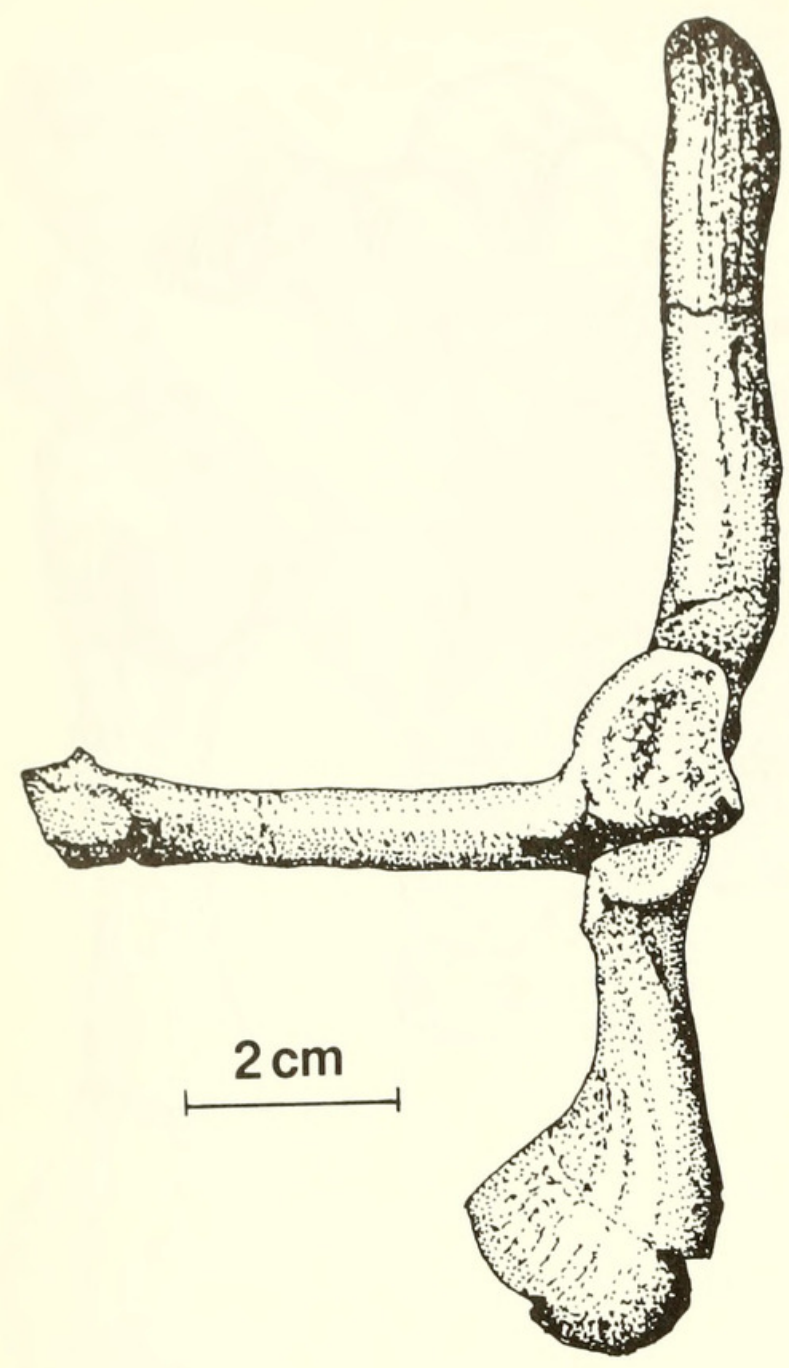

FIg. 17. Left scapulocoracoid in anterior and slightly ventral view.

ilium without a thecal process would be hypothesized as evolutionary reversals, or the reduced plastron and ligamentous plastral attachment of Emarginachelys would be hypothesized as convergence with chelydrids. Emarginachelys also has the costals not meeting behind the neurals, a biconvex 4th cervical, an elongate jugal, and non-divergent pectineal processes (see below). I prefer to regard the thecal process as independently acquired for kinosternids and Emarginachelys. A similar process occurs on ilia of some Toxochelys and of Chisternon, a baenid.

The pubis is narrower medially than in Chelydra. It is notched antero-medially for the insertion of the epipubic cartilage. Anterolaterally the pubis bears a process, the pectineal process, which was attached to the plastron by ligaments. Zug (1961) shows that only Macroclemys and Chelydra among living cryptodires have the pectineal process

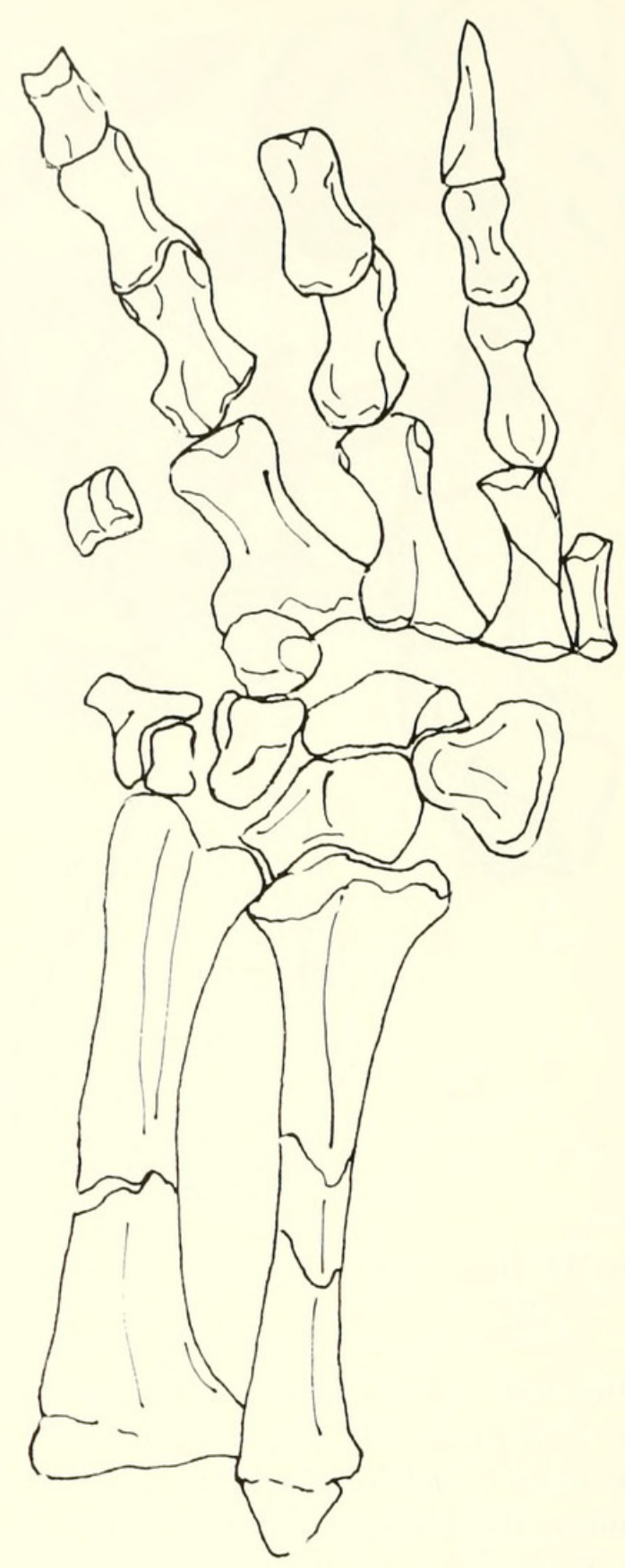

Fig. 18. Left hindfoot, tibia, and fibula. Natural size.

parallel to each other and to the sagittal plane (Fig. 20). I interpret this as a synapomorphy for advanced chelydrids. The pubis of Protochelydra is not known. The Emarginachelys pelvis is intermediate between other cryptodires and chelydrids in having the pectineal processes neither broadly divergent nor parallel.

In most testudinids, including Platysternon, the medial surfaces of the ischium and pubis are approximated, usually with a diamondshaped foramen between the two bones (Fig. 20). The pubis of living chelydrids (and 


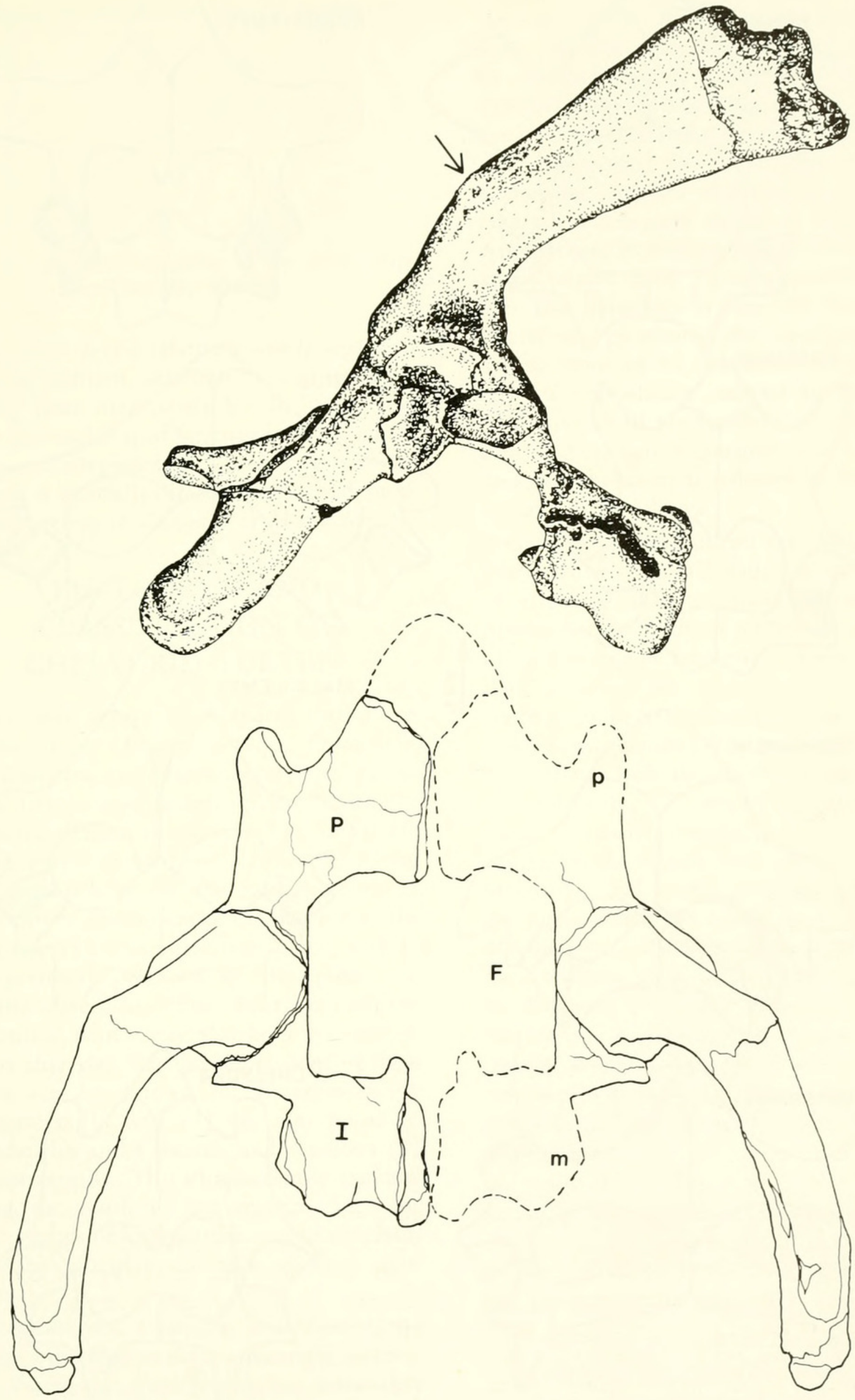

Fig. 19. Above-Left half of pelvis in lateral view. Note thecal process at arrow. Below-Partial restoration of pelvic girdle in dorsal view. Abbreviations as in Figure 20. Natural size. 


\section{$2 \mathrm{BHL}$ Biodiversity Heritage Library}

Whetstone, Kenneth N. 1978. "A new genus of Cryptodiran turtles (Testudinoidea, Chelydridae) from the Upper Cretaceous Hell Creek Formation of Montana." The University of Kansas science bulletin 51, 539-563. https://doi.org/10.5962/bhl.part.17248.

View This Item Online: https://www.biodiversitylibrary.org/item/25786

DOI: https://doi.org/10.5962/bhl.part.17248

Permalink: https://www.biodiversitylibrary.org/partpdf/17248

\section{Holding Institution}

Harvard University, Museum of Comparative Zoology, Ernst Mayr Library

\section{Sponsored by}

Harvard University, Museum of Comparative Zoology, Ernst Mayr Library

\section{Copyright \& Reuse}

Copyright Status: In copyright. Digitized with the permission of the rights holder.

License: http://creativecommons.org/licenses/by-nc-sa/3.0/

Rights: https://biodiversitylibrary.org/permissions

This document was created from content at the Biodiversity Heritage Library, the world's largest open access digital library for biodiversity literature and archives. Visit BHL at https://www.biodiversitylibrary.org. 